\title{
Determination of Metals in Natural Waters by Inductively Coupled Plasma Optical Emission Spectroscopy after Preconcentration on Silica Sequentially Coated with Layers of Polyhexamethylene Guanidinium and Sulphonated Nitrosonaphthols
}

\author{
Svetlana L. Didukh-Shadrina $\mathbb{D}^{1},{ }^{1}$ Vladimir N. Losev ${ }^{(D)},{ }^{1}$ Alexandr Samoilo, \\ Anatoliy K. Trofimchuk, ${ }^{2}$ and Pavel N. Nesterenko ${ }^{3}{ }^{3}$ \\ ${ }^{1}$ Scientific Research Engineering Centre "Kristall", Siberian Federal University, Krasnoyarsk 660041, Russia \\ ${ }^{2}$ Taras Shevchenko National University of Kyiv, Kyiv 01601, Ukraine \\ ${ }^{3}$ Chemistry Department, Lomonosov Moscow State University, Moscow 119991, Russia
}

Correspondence should be addressed to Pavel N. Nesterenko; p.nesterenko@phys.chem.msu.ru

Received 3 March 2019; Revised 22 April 2019; Accepted 22 May 2019; Published 1 July 2019

Academic Editor: Valentina Venuti

Copyright (C) 2019 Svetlana L. Didukh-Shadrina et al. This is an open access article distributed under the Creative Commons Attribution License, which permits unrestricted use, distribution, and reproduction in any medium, provided the original work is properly cited.

\begin{abstract}
A series of complexing adsorbents is prepared by coating silica particles with linear polyhexamethylene guanidinium (PHMG) chloride followed by saturation with a number of sulphonated nitrosonaphthols reagents electrostatically retained by positively charged polymer layer. PHMG coated silica is hydrolytically stable even during treatment with $6 \mathrm{M} \mathrm{HCl} \mathrm{heated} \mathrm{up} \mathrm{to} 50{ }^{\circ} \mathrm{C}$. The adsorption of 1-nitroso-2-naphthol-3,6-disulfonic acid (nitroso-R-salt), 2-nitroso-1-naphthol-4-sulfonic acid (nitroso-N-salt), and 2-nitroso-1-naphthol-3,6-disulfonic acid (nitroso-K-salt) on PHMG modified silica was studied. The effective immobilisation of sulphonated nitrosonaphthols was achieved in the range of $\mathrm{pH}$ of $3-8$, while the adsorption of the monosulphonated reagent (nitroso-N-salt) is twice as high as the disulphonated analogues (nitroso-R-salt and nitroso-K-salt). The adsorption of $\mathrm{Cu}$ (II), $\mathrm{Fe}(\mathrm{III}), \mathrm{Co}(\mathrm{II}), \mathrm{Ni}(\mathrm{II}), \mathrm{Al}(\mathrm{III}), \mathrm{Zn}(\mathrm{II}), \mathrm{Pb}(\mathrm{II}), \mathrm{Mn}(\mathrm{II})$, and $\mathrm{Cr}(\mathrm{III})$ on prepared complexing adsorbents under static and dynamic conditions was studied as a function of time, $\mathrm{pH}$, sample volume, and presence of interfering ions. Metal ions can be desorbed by using $1 \mathrm{M} \mathrm{HCl}$ or $1 \mathrm{M} \mathrm{HNO}_{3}$. The preconcentration factors of metals under optimized conditions are varied from 20 to 80 . The developed method was used for the preconcentration of trace metals from natural waters followed by ICP-OES determination. The sub-ppb limits of detection of metals are achieved.
\end{abstract}

\section{Introduction}

The determination of metal ions in natural waters at low concentration level remains one of the most important tasks in environmental monitoring. The application of various spectrometric techniques such as flame atomic-absorption spectrometry (FAAS), graphite furnace atomic spectrometry (GFAAS), inductively coupled plasma optical emission spectrometry (ICP-OES), and mass-spectrometry (ICP-MS) has been reported for multielement determination of metals [13]. The choice of right specific analytical method depends on concentration of analytes and number of metals to be detected in the sample.

However, group determination of metals at trace level in complex matrices requires sample pretreatment with the purpose of preconcentration of target analytes and/or elimination of undesirable matrix effects.

The most efficient way for the preconcentration of traces of transition and heavy metals from waters is solid phase extraction (SPE) with various types of adsorbents including chemically modified silica, nanocarbon containing materials, 
magnetic particles, chitosan based, and many others [2, 49]. Despite the wide range of adsorbents reported for the preconcentration of trace elements from natural waters, the development of new highly selective adsorbents combining simplicity of synthesis with low-cost of the production remains an important task. The selectivity of the adsorbents to the analytes is primarily determined by the nature of the functional group chemically or noncovalently fixed on the surface of solid matrices $[2,5,8,9]$.

Nitrosonaphthols and their structural analogues have attracted attention as selective ligands for the spectrophotometric and chromatographic determination of transition metals [10-12] and for the preparation of chelating adsorbents. The chelating adsorbents can be prepared by covalent attachment of 1-nitroso-2-naphthol [13] and 2-nitroso-1-naphthol [14] to macroreticular poly(styrenedivinylbenzene) (PS-DVB) resins as well as 1-nitroso-2naphthol to silica gel [15]. The possibility of the preconcentration of V(V), Cr(III), Mn(II), Fe(III), Co(II), Ni(II), Cu(II), $\mathrm{Zn}(\mathrm{II}), \mathrm{Hg}(\mathrm{II}), \mathrm{Pb}(\mathrm{II}), \mathrm{Cd}(\mathrm{II}), \mathrm{Zn}(\mathrm{II}), \mathrm{Al}(\mathrm{III}), \mathrm{Pd}(\mathrm{II})$, and $\mathrm{U}(\mathrm{VI})$ from water solutions is studied. The covalent grafting of this type of ligands to a suitable matrix is a complex task, so physical adsorption or impregnation can be used as alternative for their immobilisation of nitrosonaphthols.

The first successful application of hydrophobic PS-DVB resin impregnated with neutral 1-nitroso-2-naphthol reagent for the preconcentration of cobalt is reported by Kubo et al. in 1977 [16]. The high preconcentration factor (PF) of 67 was achieved for cobalt in this work. Aydin and Soylak used PSDVB resin MCI GEL CHP20P impregnated with structurally similar 2-nitroso-1-naphthol reagent as adsorbent for preconcentration of $\mathrm{Th}(\mathrm{IV}), \mathrm{Ti}(\mathrm{IV}), \mathrm{Fe}(\mathrm{III}), \mathrm{Pb}$ (II), and $\mathrm{Cr}$ (III) prior to ICP-MS determination [17]. The silica based adsorbent prepared by impregnation with 1-nitroso-2-naphthol was also used for the preconcentration of cobalt, while a higher PF of 100 was achieved [18].

There are few methods of using electrostatic interactions for the immobilisation of sulphonated nitrosonaphthols such as 1-nitroso-2-naphthol-3,6-disulfonic acid (nitroso-R-salt, NRS) and 2-nitroso-1-naphthol-4-sulfonic acid (nitroso-Nsalt, NNS). The simple way is based on a conversion of PS-DVB strong base anion-exchange resins into NRS form. The modification of anion-exchange resins Dowex 1 [19-22], Amberlite IRA-402, and IRA-958 [23] has been reported.

A few approaches for the preparation of chelating adsorbents containing metal-selective nitrosonaphthol functional groups have been described in the literature [24-27]. Kocjan et al. prepared chelating adsorbent by impregnation of silica with ion-pair composed of a mixture of tricaprylylmethylammonium and trioctylmethylammonium cations (Aliquat $336)$ and NRS or NNS [24, 25]. NRS containing adsorbent was used for the chromatographic separation of $\mathrm{Co}$ (II) $<\mathrm{Fe}(\mathrm{III}), \mathrm{Cu}(\mathrm{II})<\mathrm{Ni}(\mathrm{II})<\mathrm{Cd}(\mathrm{II}), \mathrm{Zn}$ (II), and $\mathrm{Mn}$ (II) with step gradient of perchloric acid as elution. A baseline separation of $\mathrm{Co}(\mathrm{II}), \mathrm{Fe}(\mathrm{III}), \mathrm{Ni}(\mathrm{II})$, and $\mathrm{Ca}(\mathrm{II})$ was obtained on a column packed with NNS containing adsorbent $[24,25]$. The authors also reported selectivity for NNS adsorbent estimated as adsorption capacities for different metals. At pH 6.0 the following selectivity was observed: $\mathrm{Co}$ (II) (14.2) $>\mathrm{Cu}$ (II) (6.9)
$>\mathrm{Ni}$ (II) $(6.4)>\mathrm{Cr}$ (III) $(5.9)>\mathrm{Pb}$ (II) $(5.1)>\mathrm{Zn}$ (II) $\approx \mathrm{Al}(\mathrm{III})$ (4.2) > Cd(II) (3.6) > Mn (2.6), and no adsorption was noted for $\mathrm{Na}(\mathrm{I}), \mathrm{K}(\mathrm{I}), \mathrm{Ca}(\mathrm{II})$, and $\mathrm{Mg}(\mathrm{II})$. It was also noted that NNS forms more stable ion-pairs with Aliquat 336 than the more hydrophilic NRS.

Later, this research group used the same approach for the preparation of chelating adsorbents by coating of hydrophobic octylsilica and octadecyl silica substrates with ion-pairs formed by Aliquat 336 and NNS [24, 25]. A complete separation of $\mathrm{Mg}$ (II) $<\mathrm{Cu}$ (II) $<\mathrm{Fe}$ (III) $<\mathrm{Co}$ (II) was obtained with gradient elution using perchloric acid as eluent.

Recently, two-step modification of silica surface was proposed for the immobilisation of negatively charged chelating reagents. At the first step bare silica is coated with linear polyhexamethylene guanidine $\left[-\left(\mathrm{CH}_{2}\right)_{6}-\mathrm{NH}-\mathrm{C}\left(=\mathrm{NH}_{2}{ }^{+} \mathrm{Cl}^{-}\right)\right.$$\mathrm{NH}-]_{\mathrm{n}}$ (PHMG) to obtain an intermediate $\mathrm{SiO}_{2}-\mathrm{PHMG}$ with positively charged surface. The prepared product is treated with solution of negatively charged organic reagents, such as sulphonated nitrosonaphthols, which are strongly retained due to electrostatic interactions [26, 27]. The resulting adsorbents had a three-layer structure formed by layers of negatively charged silanol groups and positively charged protonated PHMG polymer layer and outer layer of negatively charged chelating reagents. In this work three nitrosonaphthols containing one (nitroso-N-salt, NNS) or two sulpho (nitroso-K-salt, NKS and nitroso-R-salt, NRS) groups in their molecules (see Scheme 1) were used for the preparation of adsorbents by modification of $\mathrm{SiO}_{2}-\mathrm{PHMG}$. The PHMG coated silica modified with 1-nitroso-2-naphthol3,6-disulfonic acid (nitroso-R-salt, NRS) has been successfully used for the preconcentration and determination of Pd(II) and Co(II) $[28,29]$.

The aim of the present work is connected with preparation of three new silica based adsorbents by consecutive treatment of the surface with PHMG and sulphonated nitrosonaphthols and investigation of their adsorption properties towards a group of transition metals cations with focus on the development of ICP-OES method of natural waters analysis. The presence of oppositely charged layers at the surface of adsorbents and chelating properties of residual guanidinium groups in PHMG can influence both selectivity and kinetics of metals adsorption as indicated in the literature [30, 31].

\section{Materials and Methods}

2.1. Reagents. All reagents used in this work had analytical grade. Standard stock solutions of $\mathrm{Cu}(\mathrm{II}), \mathrm{Fe}(\mathrm{III}), \mathrm{Co}$ (II), $\mathrm{Ni}(\mathrm{II}), \mathrm{Al}(\mathrm{III}), \mathrm{Zn}(\mathrm{II}), \mathrm{Pb}(\mathrm{II}), \mathrm{Mn}(\mathrm{II})$, and $\mathrm{Cr}(\mathrm{III})$ (100 mg $\mathrm{L}^{-1}$ ) were prepared by dissolving the corresponding salts in $1 \mathrm{~mol} \mathrm{~L}^{-1}$ nitric acid and further diluted in double distilled deionized water on daily basis. $1 \mathrm{M} \mathrm{HNO}_{3}, 1$ $\mathrm{M} \mathrm{NaOH}, 0.1 \mathrm{M}$ acetate-acetic acid buffer ( $\mathrm{pH} 4.0$ 6.3), $0.5 \mathrm{M}$ ammonia-ammonium acetate buffer ( $\mathrm{pH} 6.5$ - 7.0), and 0.1 M ammonia-ammonium chloride buffer ( $\mathrm{pH} 8.0$ - 8.5) were used for $\mathrm{pH}$ adjustments. The silica gel Silokhrom S-120 (Reakhim, Stavropol, Russia) having particle size $0.1-0.2 \mathrm{~mm}$, specific surface area of $\sim 120$ $\mathrm{m}^{2} \mathrm{~g}^{-1}$, and pores of average diameter $45 \mathrm{~nm}$ was used as 
<smiles>[O]S([O-])(O[Na])c1cc2cc([N+](=O)[O-])ccc2c([N+](=O)[O-])c1O</smiles>

1-nitroso-2-naphthol-3,6disulfonic acid (nitroso-R-salt, NRS)<smiles>O=Nc1cc([N+](=O)[O-])c2ccccc2c1O</smiles>

2-nitroso-1-naphthol-4sulfonic acid (nitroso-N-salt, NNS)<smiles>O=[N+]([O-])c1ccc2c(O)c([N+](=O)[O-])c(S(=O)(=O)[O-])cc2c1</smiles>

2-nitroso-1-naphthol-3,6disulfonic acid (nitroso-K-salt, NKS)

SCHEME 1

a matrix for the preparation of adsorbents. Polyhexamethylene guanidine chloride (PHMG, 95\% pure) was supplied by the Institute of Eco-Technological Problems (Moscow, Russia). 1-Nitroso-2-naphthol-3,6-disulfonic acid (nitrosoR-salt, NRS), 2-nitroso-1-naphthol-4-sulfonic acid (nitrosoN-salt, NNS), and 2-nitroso-1-naphthol-3,6-disulfonic acid (nitroso-K-salt, NKS) were obtained from Sigma-Aldrich (St. Louis, MO, USA).

\subsection{Equipment. ICP-OES spectrometer Optima 5300DV} (Perkin-Elmer) with a cross-flow nebulizer and a Ryton Scott chamber was used for the detection of metal ions. Elemental measurements were made in axial view mode using wavelengths and operating parameters recommended for the spectrometer, which are presented in Table 1.

The $\mathrm{pH}$ values were adjusted using a Seven Easy S20 digital pH meter (Mettler-Toledo, Switzerland) calibrated using four standard buffer solutions of $\mathrm{pH} 1.65,4.01,7.00$, and 9.18. UV-Vis spectra were recorded with Cary 100 spectrophotometer (Varian, Australia). A MasterflexL/S peristaltic pump (Thermo Fisher Scientific, USA) was used for pumping solutions through a glass minicolumn (30 x $3 \mathrm{~mm}$ I.D.) containing $0.1 \mathrm{~g}$ of the sorbent.

Thermogravimetric analysis (TGA) of prepared adsorbents was performed with STA 449 C analyser (Netzsch, Germany) coupled to FTIR spectrometer Nicolet 380 via TGA/FT-IR interface (Thermo Scientific, USA). This instrument can be used for differential scanning calorimetry, thermogravimetry, and analysis of the released gas phase. FTIR spectra are used for measurement of absorbance of gases released from the sample heated in platinum crucible in the temperature range from 30 to $760^{\circ} \mathrm{C}$.

Semiempirical method PM3 of computational chemistry software GAMESS was used for the calculation of geometry of the molecules. Molecular parameters are calculated for the most stable conformational forms using geometric parameters and van der Waals atomic radii.

2.3. Preparation of Adsorbents. To activate surface silanol groups 15 grams of silica was soaked in diluted solution of $\mathrm{NaOH}$ with $\mathrm{pH} 9.0$ for 1 hour and carefully washed by deionised water until neutral $\mathrm{pH}$. Adsorbent $\mathrm{SiO}_{2}-\mathrm{PHMG}$
TABLE 1: Wavelength and operating conditions used for ICP-OES determination of metals.

\begin{tabular}{|c|c|}
\hline RF power, $\mathrm{kW}$ & 1.3 \\
\hline Plasma gas flow, $\mathrm{L} \min ^{-1}$ & 15 \\
\hline Auxiliary Ar, L min ${ }^{-1}$ & 0.2 \\
\hline Nebulizer Ar, L min ${ }^{-1}$ & 0.8 \\
\hline Pump rate, $\mathrm{mL} \min ^{-1}$ & 1.5 \\
\hline Readings/replicate & 3 \\
\hline \multirow[t]{2}{*}{ Wavelength, nm } & $\begin{aligned} \mathrm{Cu}: & 324.752 ; \mathrm{Fe}: 238.204 \text {; Co: } 238.892 \text {; Ni: } \\
& \text { 231.604; Al: 308.215; Zn: 213.857; }\end{aligned}$ \\
\hline & Pb: 220.353; Mn: 257.610; Cr: 267.709 \\
\hline
\end{tabular}

was obtained by addition of $100 \mathrm{~mL}$ of $7.5 \%$ solution of PHMG hydrochloride in water to activated silica at rate 1 $\mathrm{mL} \min ^{-1}$ and constant mixing. The prepared adsorbent was washed with deionised water until negative reaction on presence of PHMG in rinsing waters indicated by test reaction with bromphenol blue at $\mathrm{pH} 11$ in presence of sodium dodecylsulfate and chloroform as described [27]. The prepared adsorbent was dried in the air at $70^{\circ} \mathrm{C}$.

The immobilisation of sulphonated nitrosonaphthols at the surface of $\mathrm{SiO}_{2}-\mathrm{PHMG}$ was optimised by additional set of experiments. In this study $10 \mathrm{~mL}$ of sulphonated nitrosonaphthol with concentration varied from $6.8 \cdot 10^{-6} \mathrm{M}$ to $1.4 \cdot 10^{-3} \mathrm{M}$ was added to $0.1 \mathrm{~g}$ amounts of $\mathrm{SiO}_{2}-\mathrm{PHMG}$ placed in test tubes and agitated for $5 \mathrm{~min}$. The prepared adsorbents $\left(\mathrm{SiO}_{2}-\mathrm{PHMG}-\mathrm{NRS}, \mathrm{SiO}_{2}-\mathrm{PHMG}-\mathrm{NNS}\right.$, and $\mathrm{SiO}_{2}-\mathrm{PHMG}-\mathrm{NKS}$ ) were decanted and dried in the air. The adsorption of reagents was calculated from the changes in absorbance of solutions measured spectrophotometrically at $375 \mathrm{~nm}$ (NRS), $383 \mathrm{~nm}$ (NNS, $\mathrm{pH}<6.0$ ), $424 \mathrm{~nm}$ (NNS, $\mathrm{pH}>6.0)$, and $368 \mathrm{~nm}(\mathrm{NKS})$ before and after equilibration.

2.4. Investigation of Metal Ions Adsorption under Static Conditions. $10 \mathrm{~mL}$ of solutions containing $0.2 \mu \mathrm{g} \mathrm{mL}^{-1}$ of $\mathrm{Cu}$ (II), $\mathrm{Fe}(\mathrm{III}), \mathrm{Co}(\mathrm{II}), \mathrm{Ni}(\mathrm{II}), \mathrm{Al}(\mathrm{III}), \mathrm{Zn}(\mathrm{II}), \mathrm{Pb}(\mathrm{II}), \mathrm{Mn}(\mathrm{II})$, and $\mathrm{Cr}$ (III) was added to $0.1 \mathrm{~g}$ amounts of $\mathrm{SiO}_{2}$-PHMG-NRS or $\mathrm{SiO}_{2}$-PHMG-NNS. $\mathrm{pH}$ of solutions were adjusted to $\mathrm{pH} 2.0$ - 3.0 by addition of concentrated $\mathrm{HNO}_{3}$ and to $\mathrm{pH} 4.0$ 7.0 and $\mathrm{pH} 7.5-9.0$ by addition of acetate and ammonium 
chloride buffers, respectively. The mixture was agitated for 1 - $30 \mathrm{~min}$ and then residual concentration of metals in solutions was measured by ICP-OES. Additionally the metals concentrations were measured in $0.1,1,2,4$, and $6 \mathrm{M} \mathrm{HCl}$ or $\mathrm{HNO}_{3}$ solutions used for desorption of adsorbed metals.

2.5. Metal Ions Preconcentration in Dynamic Conditions. The adsorption of metal ions in dynamic mode was studied with 3 $\mathrm{cm}$ long and $3 \mathrm{~mm}$ I.D. chromatographic column containing $0.1 \mathrm{~g}$ of $\mathrm{SiO}_{2}$-PHMG-NRS or $\mathrm{SiO}_{2}$-PHMG-NNS adsorbents with maximum loadings of corresponding reagents. $10-100$ $\mathrm{mL}$ aliquots of $0.2 \mu \mathrm{g} \mathrm{mL} \mathrm{m}^{-1}$ metal ions solutions with $\mathrm{pH}$ varied from 2 to 8 were passed through the column at flow rate $0.5-5 \mathrm{~mL} \mathrm{~min}^{-1}$ by using peristaltic pump. The metals were desorbed from the column by pumping through 5 or 10 $\mathrm{mL}$ of $1 \mathrm{M} \mathrm{HNO}_{3}$. ICP-OES was used for the measurements of metal concentration in the effluents.

The efficacy of adsorbents for isolation of metals was evaluated by using preconcentration factors (PFs). Assuming both quantitative adsorption and quantitative desorption under optimised condition the values of PFs were calculated as ratio of initial sample volume to the minimal volume of the eluent required for desorption of the selected metal ion.

2.6. Sample Analysis. $100 \mathrm{~mL}$ of the sample was filtered through acetyl cellulose membrane filter with pore diameter of $0.1 \mu \mathrm{m}$ (Vladipore, Vladimir, Russia) and acidified with concentrated $\mathrm{HNO}_{3}$ to $\mathrm{pH}$ 1.0. To destroy organic substances the samples were boiled for 30 minutes; then $\mathrm{pH}$ of cooled samples was adjusted to $\mathrm{pH} 6.0$ and passed through the column at flow rate $1.5 \mathrm{~mL} \mathrm{~min}^{-1}$. Desorption of metals before their determination in effluents was performed as described in Section 2.5.

\section{Results and Discussion}

The prepared adsorbents have three layered structures composed of negatively charged silanol groups, intermediate layer of positively charged complexing polymer PHMG, and outer layer of adsorbed sulphonated reagents. The combined complexing properties are defined by the presence of nitrosonaphthols groups from the electrostatically retained reagents and unshielded guanidinium groups from PHMG layer. The ratio of nitrosonaphthol and guanidinium groups can be regulated through number of sulpho groups in the molecules of sulphonated nitrosonaphthols (one sulfo group in NNS and two in NKS) and variation of reagent loadings. The selectivity of the prepared adsorbents depends also on position of nitroso and naphthol groups in isomeric reagents NRS and NKS. On this reason the adsorption of sulphonated nitrosonaphthols on $\mathrm{SiO}_{2}$-PHMG and metal ions on the prepared complexing adsorbents was additionally investigated.

3.1. Adsorption of Sulphonated Nitrosonaphthols on $\mathrm{SiO}_{2}-$ PHMG. According to TGA data the intermediate product $\mathrm{SiO}_{2}$-PHMG contains $1.36 \%$ of loaded PHMG; therefore surface concentration of positively charged guanidinium groups can be estimated as $96 \mu$ equiv $\mathrm{g}^{-1}$ for this adsorbent.
It was found that PHMG modified silica binds quantitatively (recovery 98 - 99\%) NRS and NKS from aqueous solutions in $\mathrm{pH}$ range from 3.0 to 8.0 and NNS in $\mathrm{pH}$ range from 4.0 to 7.0 (Figure 1). Maximum adsorption capacity of $\mathrm{SiO}_{2}-\mathrm{PHMG}$ for sulfonated nitrosonaphthols was calculated from isotherms of adsorption, obtained for the saturation of the sorbent surface with reagents at $\mathrm{pH} 5$ (Figure 2). The adsorption equilibrium requires less than 5 min for all nitrosonaphthols. The decrease of adsorbed NRS, NKS, and NNS observed at $\mathrm{pH}<2$ is associated with protonation of naphthylsulfonic groups in these reagents $\left(\mathrm{pK}_{\mathrm{a}} \leq 2.5\right)$ resulting in formation of neutral molecular forms. Obviously, neutral forms of sulphonated nitrosonaphthols have strong electrostatic interactions with surface of $\mathrm{SiO}_{2}-\mathrm{PHMG}$. Similarly, the adsorption of sulphonated nitrosonaphthols decreases with increase of $\mathrm{pH}$ above 7 due to deprotonation of guanidinium groups.

Clearly, adsorption capacity values for sulfonated nitrosonaphthols depend on the charge of the molecules and were equal to $43 \mu \mathrm{mol} \mathrm{g}^{-1}$ for double charged NRS and NKS and $88 \mu \mathrm{mol} \mathrm{g}^{-1}$ for single charged NKS reagent. These are close to the maximum ion-exchange capacity $96 \mu$ equiv $\mathrm{g}^{-1}$ of $\mathrm{SiO}_{2}-\mathrm{PHMG}$, while only $10 \%$ of guanidine groups do not form ion associates with sulphonated nitrosonaphthols. It should be noted that the adsorption capacity value of $\mathrm{SiO}_{2}$-PHMG obtained for NNS is twice higher than for NRS and NKS (Figure 2).

According to computational calculations the size of monosulphonated NNS molecule is about $3.98 \mathrm{~nm}^{2}$ that is comparable with the value $4.23 \mathrm{~nm}^{2}$ calculated for disulphonated NRS molecules; therefore the difference in adsorption capacity values is due to different orientation of the molecules upon the surface of $\mathrm{SiO}_{2}$-PHMG. Possibly, NRS and NKS molecules have two interaction points being planar or parallel to the surface orientation, while NNS molecule with one binding point is perpendicular to the surface orientation. The amount of NRS adsorbed on $\mathrm{SiO}_{2}$ PHMG is higher than $20 \mu \mathrm{mol} \mathrm{g}^{-1}$ NRS loading reported in the literature for PS-DVB anion-exchange resin [20].

Obviously, sulphonated nitrosonaphthols are retained on the surface $\mathrm{SiO}_{2}-\mathrm{PHMG}$ due to electrostatic interactions between bulky polarisable organic anions and guanidinium groups from PHMG; therefore the concentration of adsorbed reagents can be sensitive to the presence of other anions. The stability of the prepared adsorbents was studied by treatment with concentrated solutions of sodium chloride and hydrochloric and nitric acids. According to the theory of ion-exchange [42] the desorption degree of single charged NNS anion is significantly higher than of double charged NRS and NKS anions for all solutions used for treatment (Tables 2 and 3). It should be noted that a small part of sulphonated nitrosonaphthols is strongly retained by $\mathrm{SiO}_{2}-\mathrm{PHMG}$ and can be desorbed only by two washes with $6 \mathrm{M}$ inorganic acid heated to $50^{\circ} \mathrm{C}$.

Acid treatment can affect the stability of the prepared adsorbents by weakening electrostatic interactions not only between sulphonated nitrosonaphthols and protonated PHMG, but also between PHMG layer and silanols groups 


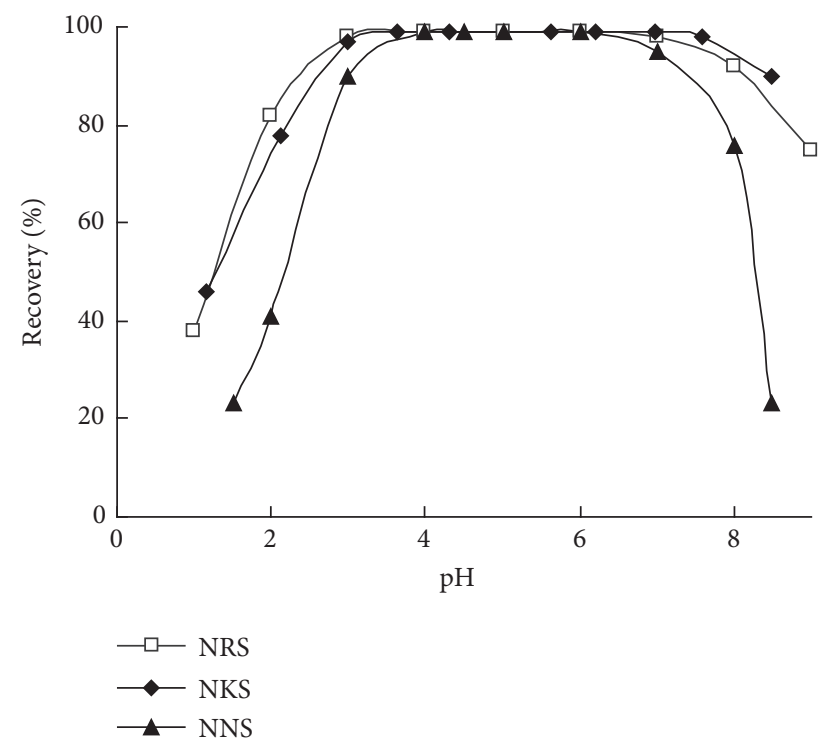

Figure 1: Effect of $\mathrm{pH}$ on NRS, NKS, and NNS adsorption on $\mathrm{SiO}_{2}-\mathrm{PHMG}$ as a function of $\mathrm{pH} . m_{\text {ads }}=0.1 \mathrm{~g}, C_{\mathrm{OR}}=2.65 \cdot 10^{-5} \mathrm{M}$, sample volume $10 \mathrm{~mL}$, and shaking time $5 \mathrm{~min}$.

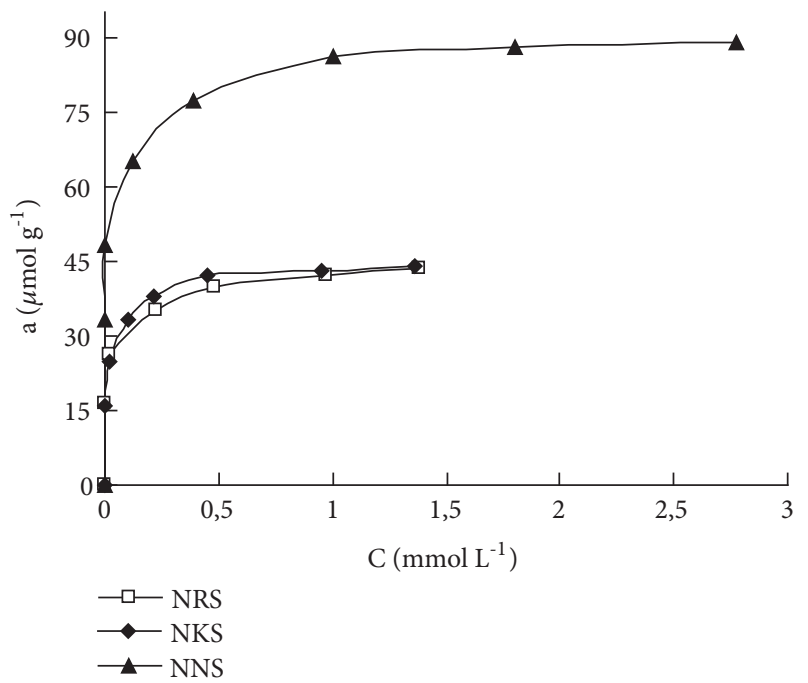

FIGURE 2: Adsorption isotherms of NRS, NKS, and NNS on $\mathrm{SiO}_{2}-\mathrm{PHMG}$ at $\mathrm{pH}$. The other conditions are as shown in Figure 1.

TABLE 2: Desorption degree $\left(R_{\text {desorb }}\right)$ NRS, NKS, and NNS from the surface of $\mathrm{SiO}_{2}$-PHMG by washing with $10 \mathrm{~mL}$ of $\mathrm{NaCl}$ solution (mass of adsorbents $0.1 \mathrm{~g}$, reagents content $40 \mu \mathrm{Mg}^{-1}, n=5, P=$ $0.95)$.

\begin{tabular}{lccc}
\hline$C_{\mathrm{NaCl}}, \mathrm{M}$ & NRS & $\begin{array}{c}R_{\text {desorb }}, \% \\
\text { NKS }\end{array}$ & NNS \\
\hline 0.05 & 1.5 & 1.0 & 6 \\
0.1 & 12 & 13 & 17 \\
0.25 & 15 & 15 & 20 \\
0.5 & 18 & 19 & 27 \\
1.5 & 56 & 55 & 61 \\
\hline
\end{tabular}

from the silica backbone. However, our investigation demonstrated excellent stability of $\mathrm{SiO}_{2}-\mathrm{PHMG}$. Figure 3 shows the

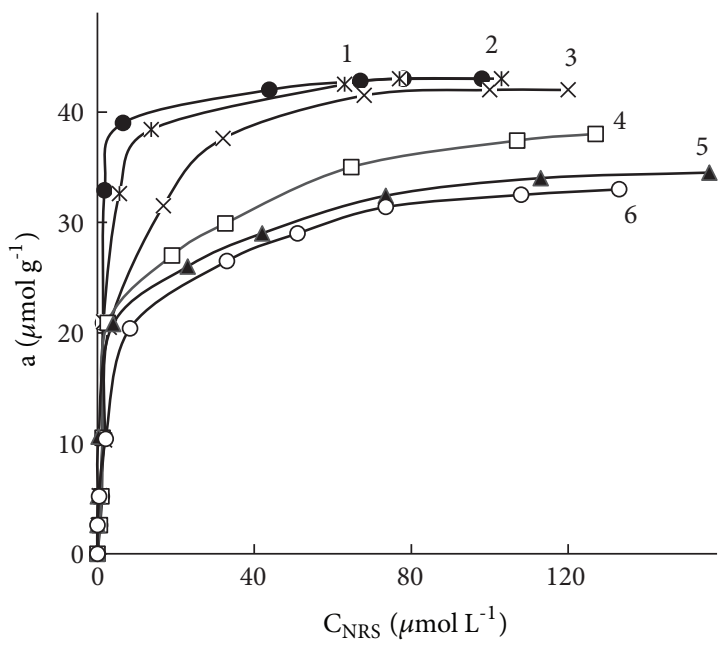

FIgure 3: Adsorption isotherms of $\mathrm{NRS}$ on $\mathrm{SiO}_{2}-\mathrm{PHMG}$ before (1) and after one (2), two (3), three (4), four (5), and five (6) treatments of $\mathrm{SiO}_{2}-\mathrm{PHMG}-\mathrm{NRS}$ with $10 \mathrm{~mL}$ of hot $\left(50^{\circ} \mathrm{C}\right) 6 \mathrm{M} \mathrm{HCl}$. Mass of adsorbent- $0.1 \mathrm{~g}$, other details of experiments as listed in Figure 1.

isotherm of adsorption of NRS on the surface of $\mathrm{SiO}_{2}-\mathrm{PHMG}$ treated few times with hot $\left(50^{\circ} \mathrm{C}\right) 6 \mathrm{M} \mathrm{HCl}$. Clearly, as shown in Figure 3 the adsorption of NRS did not change dramatically at least after three such treatments. It means that $\mathrm{SiO}_{2}-\mathrm{PHMG}$ can be reloaded with NRS and reused few times if required.

3.2. TGA of $\mathrm{SiO}_{2}-\mathrm{PHMG}-\mathrm{NRS}$ and $\mathrm{SiO}_{2}-\mathrm{PHMG}-\mathrm{NNS}$. To identify the decomposition products of adsorbents a series of thermogravimetric analyses combined with infrared detection (TGA-FTIR) of released gases was performed separately for silica, $\mathrm{SiO}_{2}-\mathrm{PHMG}, \mathrm{SiO}_{2}-\mathrm{PHMG}-\mathrm{NRS}$, and $\mathrm{SiO}_{2}-\mathrm{PHMG}-\mathrm{NNS}$ samples. For this purpose all samples were analysed at heating up to $760^{\circ} \mathrm{C}$ in the air flow. No gas release was noted for analysis of silica except for small amount of water vapours. TGA of $\mathrm{SiO}_{2}$-PHMG showed onestep decomposition of PHMG layer with release of ammonia and cyclohexane, while maximum decomposition rate was observed at $257^{\circ} \mathrm{C}$.

A more complex decomposition occurred in the case of final adsorbents. Figures 4 and 5 show TGA and profiles of released decomposition gases for adsorbent $\mathrm{SiO}_{2}-\mathrm{PHMG}-\mathrm{NNS}$. There are three steps in the decomposition process, which are related to the corresponding maxima in differential TGA curve. As mentioned above maximum at $262^{\circ} \mathrm{C}$ corresponds to decomposition of PHMG layer (Figure 4). Decomposition of adsorbed NNS occurred at $363^{\circ} \mathrm{C}$ with release of $\mathrm{SO}_{2}$ due to transformation of sulpho groups followed by oxidation of hydrocarbon residue with release of $\mathrm{CO}_{2}$ at $537^{\circ} \mathrm{C}$ (Figure 5). These data are confirmed by DSC profile (Figure 4 ).

\subsection{Adsorption of Metal Ions under Static Conditions}

3.3.1. Effect of $p H$. The adsorption of transition metal cations was studied with complexing adsorbents $\mathrm{SiO}_{2}-\mathrm{PHMG}-\mathrm{NRS}$ 


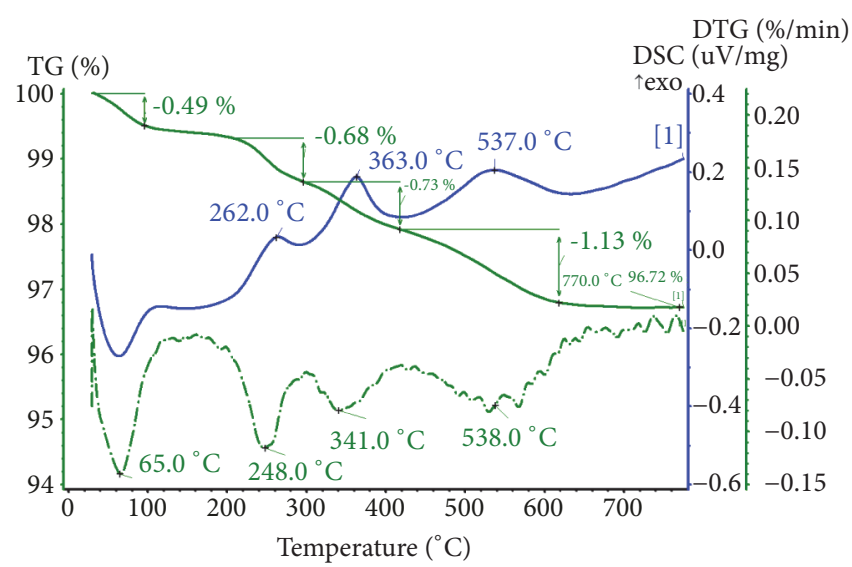

FIGURE 4: Data on total (solid dark line, TG, \%) and differential mass (solid light line, DTG, \%/min) changes of $\mathrm{SiO}_{2}-\mathrm{PHMG}_{\mathrm{N}} \mathrm{NNS}$ obtained at heat rate $10 \mathrm{~K} / \mathrm{min}$ at the air flow rate $50 \mathrm{~mL} / \mathrm{min}$. DSC profile is shown by dashed line. Similar dependences were observed during TGA-FTIR analysis of $\mathrm{SiO}_{2}-\mathrm{PHMG}-\mathrm{NRS}$.

TABLE 3: Desorption degree of reagents NRS, NKS, and NNS from the surface of $\mathrm{SiO}_{2}-\mathrm{PHMG}$ by washing with $10 \mathrm{~mL}$ of $\mathrm{HNO}$ or $\mathrm{HCl}$ solutions (mass of adsorbents $0.1 \mathrm{~g}$, reagents content $40 \mu \mathrm{Mg}^{-1}, n=5, P=0.95$ ).

\begin{tabular}{|c|c|c|c|c|c|c|}
\hline \multirow{3}{*}{$C_{\text {acid }}, M$} & \multicolumn{6}{|c|}{$R_{\text {desorb }}, \%$} \\
\hline & & $\mathrm{HNO}_{3}$ & & & $\mathrm{HCl}$ & \\
\hline & NRS & NKS & NNS & NRS & NKS & NNS \\
\hline 0.001 & 0.2 & 0.2 & 10 & 0.4 & 0.5 & 6.5 \\
\hline 0.01 & 11 & 10 & 50 & 20 & 20 & 45 \\
\hline 0.1 & 30 & 29 & 71 & 46 & 45 & 77 \\
\hline 1 & 77 & 77 & 81 & 84 & 84 & 86 \\
\hline 6 & 88 & 90 & 90 & 88 & 88 & 90 \\
\hline $6^{a}$ & 98 & 98 & 97 & 96 & 98 & 97 \\
\hline
\end{tabular}

$a_{\text {-desorption with two volumes of hot }\left(50^{\circ} \mathrm{C}\right) 6 \mathrm{M} \text { acid }}$

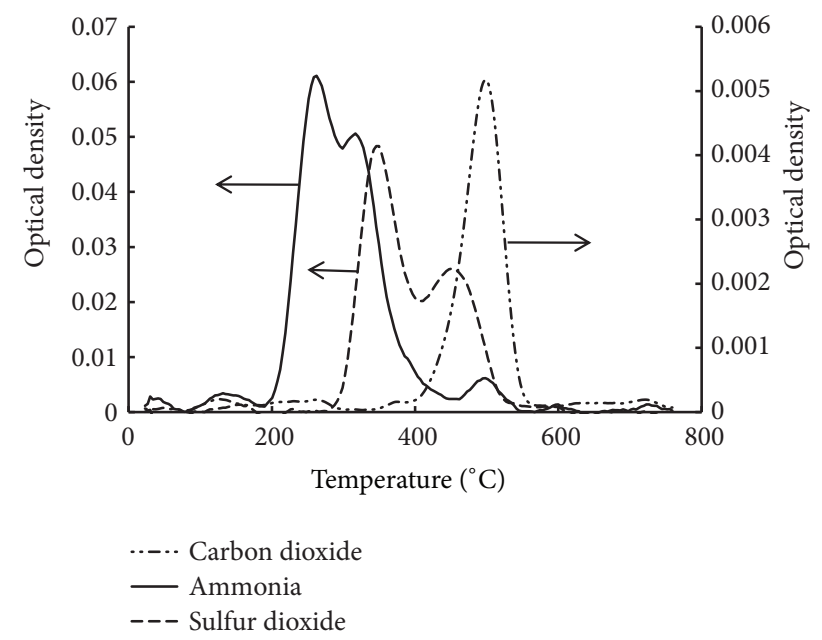

FIGURE 5: Temperature profiles of gases released during heating of $\mathrm{SiO}_{2}-\mathrm{PHMG}-\mathrm{NNS}$ as measured by FTIR.

and $\mathrm{SiO}_{2}-\mathrm{PHMG}-\mathrm{NNS}$ having different position of nitroso and naphthol groups in the molecules and different number of sulpho groups. It should be noted that due to the different charge of the molecules the concentration of adsorbed NNS in $\mathrm{SiO}_{2}-\mathrm{PHMG}-\mathrm{NNS}$ is twice higher than concentration of NRS in $\mathrm{SiO}_{2}-\mathrm{PHMG}-\mathrm{NRS}$. Obviously, both factors can influence the adsorption of metal ions. The adsorption of $\mathrm{Cu}(\mathrm{II}), \mathrm{Fe}(\mathrm{III}), \mathrm{Co}(\mathrm{II}), \mathrm{Ni}(\mathrm{II}), \mathrm{Al}(\mathrm{III}), \mathrm{Zn}$ (II), $\mathrm{Pb}$ (II), Mn(II), and $\mathrm{Cr}$ (III) was studied under static conditions from the aqueous solutions containing all metals in $\mathrm{pH}$ range from 2.0 to 8.5. It was found that adsorbent $\mathrm{SiO}_{2}-\mathrm{PHMG}-\mathrm{NRS}$ extracted quantitatively ( $\geq 98 \%) \mathrm{Fe}(\mathrm{III})$ at $\mathrm{pH}>2, \mathrm{Cu}(\mathrm{II})$ and $\mathrm{Co}$ (II) at $\mathrm{pH} \geq 4.0, \mathrm{Ni}$ (II) and $\mathrm{Al}$ (III) at $\mathrm{pH} \geq 5$, and $\mathrm{Zn}$ (II) at $\mathrm{pH} \geq 7$ as shown in Figure 6(a). Maximum extraction of $\mathrm{Pb}$ (II) and $\mathrm{Mn}(\mathrm{II})$ of 85 и 70\%, respectively, was achieved at $\mathrm{pH}>7$, and adsorption of $\mathrm{Cr}$ (III) did not exceed $45 \%$ at $\mathrm{pH} 6$ -8 .

Similar dependences of recovery of $\mathrm{Cu}(\mathrm{II}), \mathrm{Fe}(\mathrm{III}), \mathrm{Co}(\mathrm{II})$, $\mathrm{Ni}(\mathrm{II}), \mathrm{Al}(\mathrm{III}), \mathrm{Zn}$ (II), $\mathrm{Pb}$ (II), $\mathrm{Mn}$ (II), and $\mathrm{Cr}$ (III) on $\mathrm{pH}$ were obtained for the adsorbent $\mathrm{SiO}_{2}-\mathrm{PHMG}-\mathrm{NNS}$ (Figure 6(b)). The lower recovery values of $\mathrm{Cu}(\mathrm{II}), \mathrm{Fe}(\mathrm{III})$, and $\mathrm{Co}(\mathrm{II})$ at pH 2 - 3 were observed as compared with data obtained with $\mathrm{SiO}_{2}-\mathrm{PHMG}-\mathrm{NNS}$, which is more stable under acidic conditions (see Figure 1). In general the $\mathrm{pH}$ dependences are in agreement with stability constants of metals complexes with sulphonated nitrosonaphthols shown in Table 4.

3.3.2. Effect of Time. The effect of shaking time (varied from 2 to $40 \mathrm{~min}$ ) on adsorption of seven metal cations was studied 


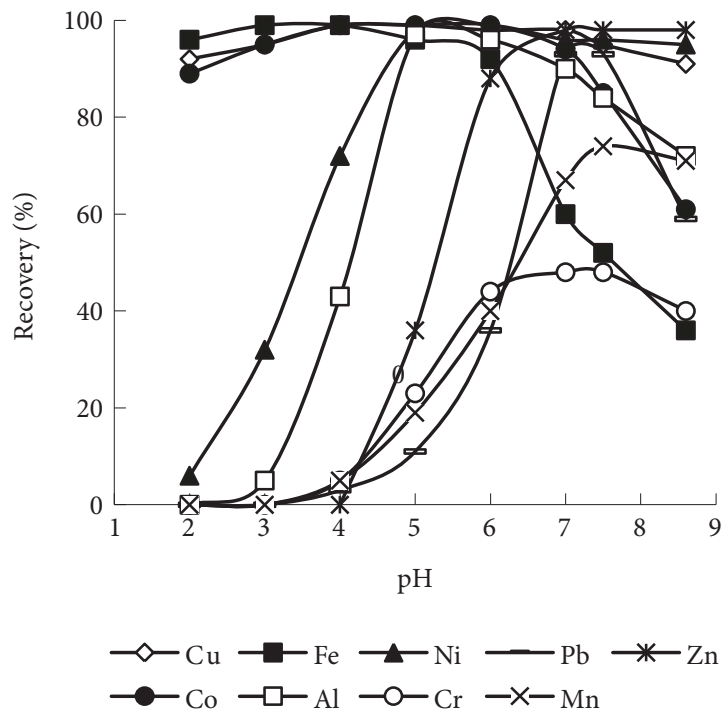

(a)

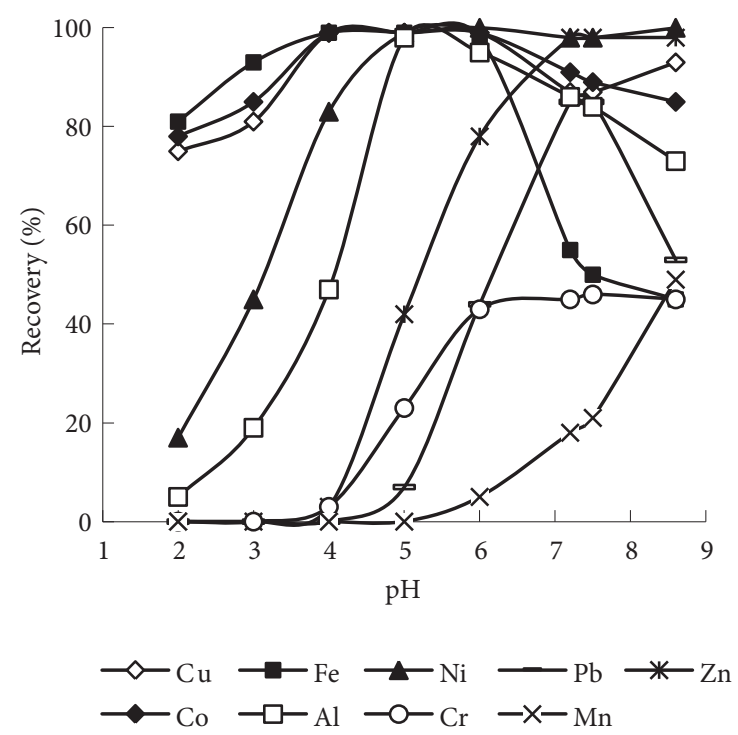

(b)

Figure 6: Effect of $\mathrm{pH}$ on adsorption of $0.2 \mu \mathrm{g} \mathrm{mL}^{-1} \mathrm{Cu}$ (II), $\mathrm{Fe}(\mathrm{III}), \mathrm{Co}(\mathrm{II}), \mathrm{Ni}$ (II), $\mathrm{Al}(\mathrm{III}), \mathrm{Zn}$ (II), $\mathrm{Pb}$ (II), $\mathrm{Mn}$ (II), and $\mathrm{Cr}$ (III) on $\mathrm{SiO}_{2}-\mathrm{PHMG}-\mathrm{NRS}$ (a) and on $\mathrm{SiO}_{2}-$ PHMG-NNS (b). Mass of adsorbent- $0.1 \mathrm{~g}$, sample volume $10 \mathrm{~mL}$, and shaking time $10 \mathrm{~min}$.

under static conditions. It was found that agitation of sample with adsorbent for $3 \mathrm{~min}$ is sufficient to achieve maximum recovery (> 98\%) of $\mathrm{Fe}(\mathrm{III}), \mathrm{Co}(\mathrm{II})$, and $\mathrm{Al}(\mathrm{III})$. Quantitative recoveries of $\mathrm{Cu}(\mathrm{II})$ and $\mathrm{Ni}(\mathrm{II})$ required $5 \mathrm{~min}$, and $10 \mathrm{~min}$ was required for complete recovery of $\mathrm{Zn}$ (II) and $\mathrm{Pb}$ (II). These results prove the excellent kinetics of adsorption of studied metal ions on the adsorbents $\mathrm{SiO}_{2}-\mathrm{PHMG}-\mathrm{NRS}$ and $\mathrm{SiO}_{2}-\mathrm{PHMG}-\mathrm{NNS}$. At $\mathrm{pH} 7.0$ the optimum adsorption time for all studied metals was achieved after $10 \mathrm{~min}$ and this time was used in further experiments.

3.3.3. Adsorption Capacity. The adsorption capacity is an important characteristic of adsorbent showing how many adsorbents are required for the removal of specific amount of metal ions from the solutions. The adsorption capacity was measured for $\mathrm{Cu}(\mathrm{II}), \mathrm{Ni}(\mathrm{II}), \mathrm{Fe}(\mathrm{III})$, and $\mathrm{Co}(\mathrm{II})$ containing samples according to procedure described in Section 2.4. The dependences of adsorption of metals $\left(\mu \mathrm{mol} \mathrm{g}^{-1}\right)$ versus the concentration of metal ions $\left(\mu \mathrm{mol} \mathrm{L}{ }^{-1}\right)$ are presented in Figure 7. According to the obtained results, the $\mathrm{SiO}_{2}$-PHMGNRS can extract $21.0 \mu \mathrm{mol} \mathrm{g}{ }^{-1}$ of $\mathrm{Cu}(\mathrm{II}), 13.8 \mu \mathrm{mol} \mathrm{\textrm {g } ^ { - 1 }}$ of $\mathrm{Ni}(\mathrm{II}), 14.7 \mu \mathrm{mol} \mathrm{g}^{-1}$ of $\mathrm{Fe}(\mathrm{III})$, and $14.1 \mu \mathrm{mol} \mathrm{g}-1$ of Co(II) jointly presented in the sample. The adsorption capacity of $\mathrm{SiO}_{2}$-PHMG-NNS for $\mathrm{Cu}(\mathrm{II}), \mathrm{Ni}(\mathrm{II}), \mathrm{Fe}(\mathrm{III})$, and $\mathrm{Co}(\mathrm{II})$ was 42.7, 29.0, 32.5, and $29.8 \mu \mathrm{mol} \mathrm{g}^{-1}$, respectively. Obviously, $\mathrm{SiO}_{2}$-PHMG-NNS has a much higher adsorption capacity for metal ions, which was related to the higher concentration NNS on surface of $\mathrm{SiO}_{2}$-PHMG $\left(88 \mu \mathrm{mol} \mathrm{g}^{-1}\right)$.

\subsection{Preconcentration of Metal Ions in Dynamic Mode}

3.4.1. Effect of $p H$. The adsorption of $\mathrm{Cu}(\mathrm{II}), \mathrm{Fe}(\mathrm{III}), \mathrm{Co}(\mathrm{II})$, $\mathrm{Ni}(\mathrm{II}), \mathrm{Al}(\mathrm{III}), \mathrm{Zn}(\mathrm{II})$, and $\mathrm{Pb}(\mathrm{II})$ was also studied under dynamic condition according to procedure described in Section 2.5. There were no observed changes in $\mathrm{pH}$ ranges of quantitative recovery (> 98\%) of $\mathrm{Fe}(\mathrm{III}), \mathrm{Co}(\mathrm{II})$, and $\mathrm{Al}$ (III), but these $\mathrm{pH}$ ranges were broader and shifted to acidic region with $\mathrm{pH} 3-7,4-7.5$, and $6.5-8.0$ for $\mathrm{Cu}(\mathrm{II}), \mathrm{Ni}(\mathrm{II})$, and $\mathrm{Zn}$ (II), respectively. The complete adsorption of $\mathrm{Pb}$ (II) was achieved at $\mathrm{pH}$ 6.5; therefore this value was selected as the optimum for column procedure.

3.4.2. Effect of the Flow Rate. The increase of sample flow rate allowed significant decrease of time required for the analysis of the samples of big volume. The effect of the flow rate on retention of the studied ions was investigated under the optimum conditions. The flow rates were varied in the range of $0.5-6.0 \mathrm{~mL} \mathrm{~min}{ }^{-1}$. It was found that the recoveries of $\mathrm{Cu}(\mathrm{II}), \mathrm{Fe}(\mathrm{III}), \mathrm{Co}(\mathrm{II})$, and $\mathrm{Al}(\mathrm{III})$ on $\mathrm{SiO}_{2}$-PHMG-NRS and $\mathrm{SiO}_{2}$-PHMG-NNS were practically not changed up to the flow rate of $5 \mathrm{~mL} \mathrm{~min}^{-1}$. The increase of flow rate to 2.5 $\mathrm{mL} \min ^{-1}$ decreased recovery of $\mathrm{Ni}$ (II) to $90 \%$. At the same time, the recoveries $\mathrm{Zn}$ (II) and $\mathrm{Pb}$ (II) decreased significantly at flow rates higher than $1.5 \mathrm{~mL} \mathrm{~min}^{-1}$. Based on these results, $1.5 \mathrm{~mL} \mathrm{~min}^{-1}$ was selected as optimum flow rate for column preconcentration procedure.

3.4.3. Effect of Sample Volume. The efficient preconcentration of metals from big sample volumes is vital for their determination in waters at trace levels. At the same time the concentration of certain metals, for example, iron, could be significantly higher than other metals considered in this work. On this reason a model solution containing $200 \mathrm{ng}$ $\mathrm{mL}^{-1}$ of $\mathrm{Fe}(\mathrm{III}), 50 \mathrm{ng} \mathrm{\textrm {mL } ^ { - 1 }}$ each of $\mathrm{Cu}(\mathrm{II}), \mathrm{Al}(\mathrm{III})$, and $\mathrm{Zn}$ (II), and $20 \mathrm{ng} \mathrm{mL}^{-1}$ each of $\mathrm{Co}(\mathrm{II}), \mathrm{Ni}(\mathrm{II})$, and $\mathrm{Pb}$ (II) with $\mathrm{pH} 6.5$ was used for the investigation of the recovery 
TABLE 4: pKa values of 1-nitroso-2-naphthol-3,6-disufonic acid and 2-nitroso-1-naphthol-4-sufonic acids and stability of their complexes with transition metals $\left(25^{\circ} \mathrm{C}, \mu=0.1\right)$ [32].

\begin{tabular}{|c|c|c|c|c|c|c|}
\hline \multirow[b]{2}{*}{ Metal } & \multicolumn{3}{|c|}{$\begin{array}{l}\text { 1-Nitroso-2-naphthol-3,6-disufonic acid } \\
\qquad \mathrm{p} K_{\mathrm{a} 1}=6.87\end{array}$} & \multicolumn{3}{|c|}{$\begin{array}{l}\text { 2-Nitroso-1-naphthol-4-sufonic acid } \\
\qquad \mathrm{pK}_{\mathrm{a} 1}=6.15\end{array}$} \\
\hline & $\log \beta_{1}$ & $\log \beta_{2}$ & $\log \beta_{3}$ & $\log \beta_{1}$ & $\log \beta_{2}$ & $\log \beta_{3}$ \\
\hline $\mathrm{Mn}(\mathrm{II})$ & 2.68 & & & $2.19^{a}$ & & \\
\hline Cd(II) & 3.42 & 6.00 & & 2.45 & & \\
\hline $\mathrm{Zn}(\mathrm{II})$ & 4.46 & 7.10 & & 3.15 & & \\
\hline $\mathrm{Pb}(\mathrm{II})$ & 4.64 & 7.83 & & 3.94 & & \\
\hline $\mathrm{Co}(\mathrm{II})$ & 5.40 & & & 4.34 & & \\
\hline $\mathrm{Ni}(\mathrm{II})$ & 6.90 & 12.5 & 17.3 & 5.50 & 10.42 & 14.45 \\
\hline $\mathrm{Cu}(\mathrm{II})$ & $9.90^{a}$ & $15.6^{a}$ & & $7.90^{a}$ & $13.10^{a}$ & \\
\hline
\end{tabular}

$a-\mu=0$

TABLE 5: Elution (\%) of metal ions adsorbed on $\mathrm{SiO}_{2}-\mathrm{PHMG}-\mathrm{NRS}$ and $\mathrm{SiO}_{2}-\mathrm{PHMG}-\mathrm{NNS}$ with nitric acid solutions (eluent volume is $10 \mathrm{~mL}$ ).

\begin{tabular}{|c|c|c|c|c|c|c|}
\hline \multirow{2}{*}{ Metal } & \multicolumn{3}{|c|}{$\mathrm{SiO}_{2}$-PHMG-NRS } & \multicolumn{3}{|c|}{$\mathrm{SiO}_{2}$-PHMG-NNS } \\
\hline & $0.1 \mathrm{M} \mathrm{HNO}_{3}$ & $1 \mathrm{M} \mathrm{HNO}_{3}$ & $2 \mathrm{M} \mathrm{HNO}_{3}$ & $0.1 \mathrm{M} \mathrm{HNO}_{3}$ & $1 \mathrm{M} \mathrm{HNO}_{3}$ & $2 \mathrm{M} \mathrm{HNO}_{3}$ \\
\hline $\mathrm{Cu}(\mathrm{II})$ & 50.3 & 99.5 & 99.8 & 65.2 & 99.4 & 99.9 \\
\hline $\mathrm{Fe}(\mathrm{III})$ & 30.8 & 99.5 & 99.9 & 37.5 & 99.7 & 99.8 \\
\hline $\mathrm{Co}(\mathrm{II})$ & - & 8.5 & 12.0 & - & 8.3 & 10.7 \\
\hline $\mathrm{Al}(\mathrm{III})$ & 78.5 & 99.9 & 99.9 & 85.9 & 99.6 & 99.8 \\
\hline $\mathrm{Ni}(\mathrm{II})$ & 68.2 & 99.3 & 99.9 & 70.4 & 99.8 & 99.9 \\
\hline $\mathrm{Zn}(\mathrm{II})$ & 83.4 & 99.9 & 99.8 & 89.4 & 99.8 & 99.8 \\
\hline $\mathrm{Pb}(\mathrm{II})$ & 88.8 & 99.2 & 99.5 & 90.6 & 99.5 & 99.5 \\
\hline
\end{tabular}

of metals as a function of sample volume passed through the column packed with $0.1 \mathrm{~g}$ of either $\mathrm{SiO}_{2}$-PHMG-NRS or $\mathrm{SiO}_{2}$ - PHMG-NNS at flow rate $1.5 \mathrm{~mL} \mathrm{~min}^{-1}$. The concentration of metals was determined in every $10 \mathrm{~mL}$ portion of the effluent by ICP-OES. The results obtained for column packed with $\mathrm{SiO}_{2}$-PHMG-NRS are shown in Figure 8. The complete extraction of all metal cations was achieved for sample volumes less than $100 \mathrm{~mL}$. An increase of model solution volumes up to $120 \mathrm{~mL}$ results in column breakthrough with recovery of $\mathrm{Pb}(\mathrm{II})$ and $\mathrm{Zn}(\mathrm{II})$ at the levels 45 and $88 \%$, respectively. After passing $150 \mathrm{~mL}$ of model solution no more extraction was observed for $\mathrm{Pb}(\mathrm{II})$ and $\mathrm{Zn}$ (II), while recovery of $\mathrm{Ni}$ (II) decreases to $58 \%$. Finally, $200 \mathrm{~mL}$ of model sample solution was loaded and a complete recovery (>98\%) was obtained only for $\mathrm{Cu}$ (II) and Fe(III). The observed extraction efficiency is in good agreement with values of stability of complexes of studied metals with NRS.

It was found that the column packed with $0.2 \mathrm{~g} \mathrm{SiO}_{2}-$ PHMG-NRS can provide complete recovery of all metals from $200 \mathrm{~mL}$ of model solutions. Certainly, for analysis of relatively pure natural waters such as mineral, tap, and mountain river water the sample volume can be also increased. The increased volume $400 \mathrm{~mL}$ of model solution was passed through the column packed with $\mathrm{SiO}_{2}$-PHMGNNS. A complete recovery of $\mathrm{Cu}$ (II) and $\mathrm{Fe}(\mathrm{III})$ was observed in the whole volume of passed sample, of $\mathrm{Al}(\mathrm{III}), \mathrm{Co}$ (II), and $\mathrm{Pb}$ (II) in $360 \mathrm{~mL}$, of $\mathrm{Co}$ (II) in $280 \mathrm{~mL}$, and of $\mathrm{Pb}$ (II) and $\mathrm{Zn}(\mathrm{II})$ in $200 \mathrm{~mL}$. Compared with $\mathrm{SiO}_{2}$-PHMG-NRS the maximum volume of model solution passed through the column containing $0.1 \mathrm{~g}$ of $\mathrm{SiO}_{2}$-PHMG-NNS with complete extraction of all metals is increased to $200 \mathrm{~mL}$. Obviously, this is due to the higher reagent loading in the case of $\mathrm{SiO}_{2}$ PHMG-NNS.

3.5. Desorption of Metals. The efficacy of complexing adsorbents in analysis of waters by ICP-OES depends on both quantitative adsorption of metals from the diluted solution and complete desorption of adsorbed metals in the smallest possible volume. The desorption of metals from $\mathrm{SiO}_{2}$ PHMG-NNS and $\mathrm{SiO}_{2}$-PHMG-NRS was studied by using $10 \mathrm{~mL}$ of $\mathrm{HCl}$ and $\mathrm{HNO}_{3}$ of concentration varied from 0.1 to $6 \mathrm{M}$. It was demonstrated that desorption degree of $\mathrm{Cu}(\mathrm{II}), \mathrm{Fe}(\mathrm{III}), \mathrm{Ni}(\mathrm{II}), \mathrm{Al}(\mathrm{III}), \mathrm{Zn}$ (II), and $\mathrm{Pb}$ (II) under static conditions does not depend on type of acid and reached maximum with $1 \mathrm{M}$ solutions of $\mathrm{HNO}_{3}$ (Table 5).

Under dynamic conditions the desorption of metal ions was studied using column filled with $0.1 \mathrm{~g}$ of $\mathrm{SiO}_{2}$-PHMGNRS or $\mathrm{SiO}_{2}$-PHMG-NNS adsorbents and 5 or $10 \mathrm{~mL}$ of 1 $\mathrm{M} \mathrm{HNO}_{3}$ as eluent. The results showed that the quantitative desorption of $\mathrm{Cu}(\mathrm{II}), \mathrm{Fe}(\mathrm{III}), \mathrm{Ni}$ (II), $\mathrm{Al}(\mathrm{III}), \mathrm{Zn}(\mathrm{II})$, and $\mathrm{Pb}$ (II) was achieved by passing $5 \mathrm{ml}$ of $1 \mathrm{M} \mathrm{HNO}_{3}$ at flow rate of $1 \mathrm{~mL} \mathrm{~min}{ }^{-1}$ or $10 \mathrm{~mL}$ of $1 \mathrm{M} \mathrm{HNO}_{3}$ at flow rate of $2 \mathrm{~mL} \mathrm{~min}{ }^{-1}$. Some part of loaded reagents is desorbed together with metals. However, the low concentration of the organic reagents in the eluate does not affect the ICP-OES determination of metals.

Quantitative desorption of $\mathrm{Co}$ (II) from the surface of adsorbents was not achieved either in static or in dynamic mode even with $6 \mathrm{M}$ acids. The adsorbents remain colored red, which is characteristic for $\left[\mathrm{CoL}_{3}\right]^{6-}$ complexes (where 
TABLE 6: LOD values of ICP-OES analysis and preconcentration factors (PF) obtained for selected metal ions with different adsorbents.

\begin{tabular}{|c|c|c|c|c|c|c|}
\hline \multirow{2}{*}{ Metal } & \multicolumn{3}{|c|}{$\mathrm{SiO}_{2}$-PHMG-NRS } & \multicolumn{3}{|c|}{$\mathrm{SiO}_{2}$-PHMG-NNS } \\
\hline & $\begin{array}{c}\mathrm{LOD}, \\
\mathrm{ng} \mathrm{mL}^{-1}\end{array}$ & $\mathrm{PF}$ & RSD, \% & $\begin{array}{c}\text { LOD, } \\
\mathrm{ng} \mathrm{mL}^{-1}\end{array}$ & $\mathrm{PF}$ & $\mathrm{RSD}, \%$ \\
\hline $\mathrm{Cu}(\mathrm{II})$ & 0.76 & 40 & 0.68 & 0.75 & 80 & 0.77 \\
\hline $\mathrm{Fe}(\mathrm{III})$ & 0.83 & 40 & 1.47 & 0.82 & 80 & 1.35 \\
\hline $\mathrm{Al}(\mathrm{III})$ & 1.34 & 32 & 2.17 & 1.35 & 66 & 2.23 \\
\hline $\mathrm{Ni}(\mathrm{II})$ & 0.95 & 26 & 1.64 & 0.96 & 28 & 1.52 \\
\hline $\mathrm{Zn}(\mathrm{II})$ & 0.77 & 24 & 0.89 & 0.77 & 30 & 0.93 \\
\hline $\mathrm{Pb}(\mathrm{II})$ & 0.87 & 20 & 2.35 & 0.88 & 42 & 1.98 \\
\hline
\end{tabular}

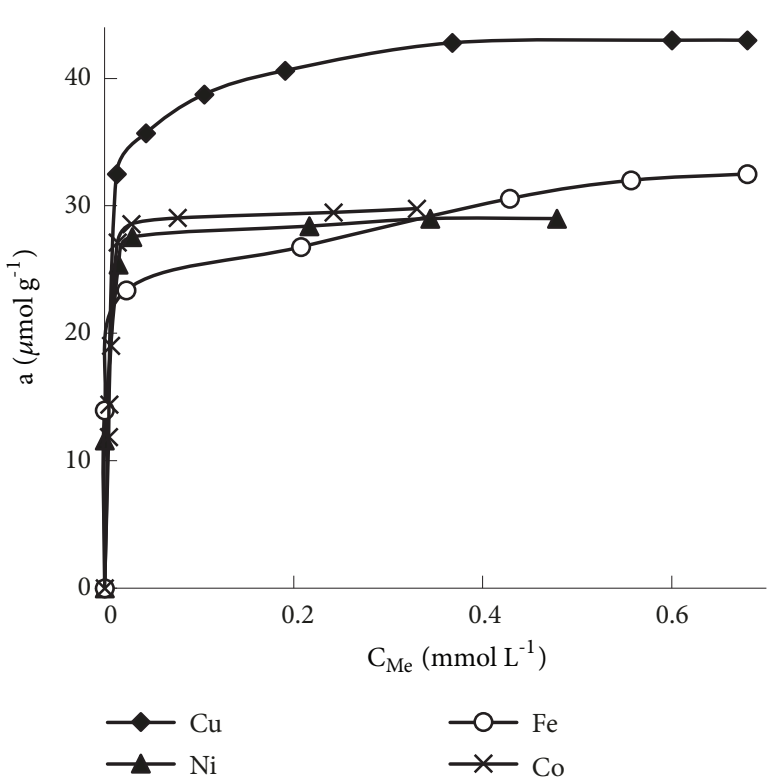

(a)

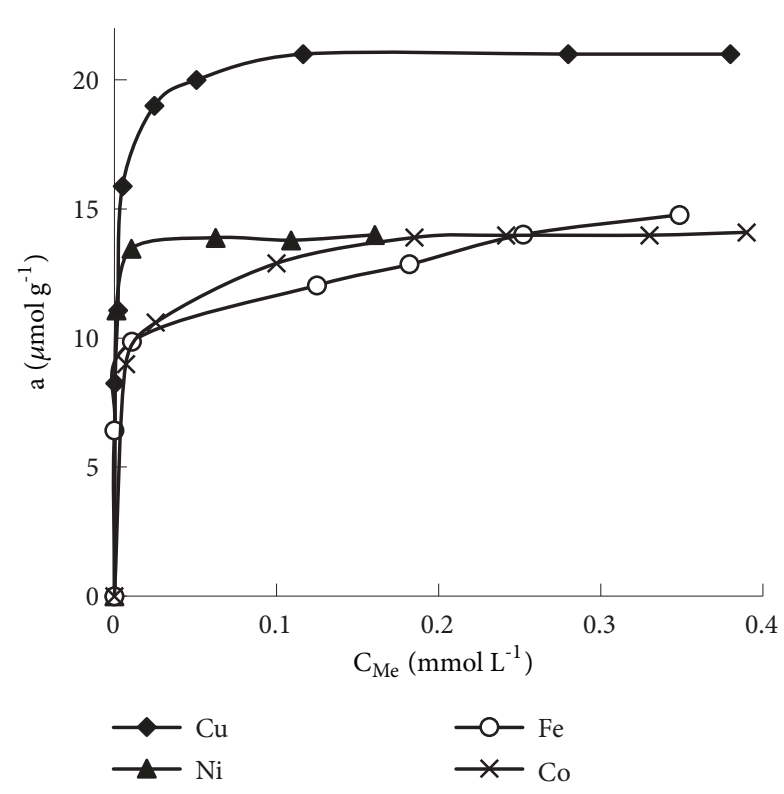

(b)

Figure 7: Adsorption capacity of $\mathrm{Cu}(\mathrm{II}), \mathrm{Ni}(\mathrm{II}), \mathrm{Fe}(\mathrm{III})$, and $\mathrm{Co}(\mathrm{II})$ on $\mathrm{SiO}_{2}$-PHMG-NRS (a) and $\mathrm{SiO}_{2}$-PHMG-NNS (b). Mass of adsorbent$0.1 \mathrm{~g}$, sample volume $10 \mathrm{~mL}$, and shaking time $10 \mathrm{~min}$.

L is NRS or NNS), even in strongly acidic media. In this case, the Co concentration can be determined by a sorptionphotometric method directly in the phase of the adsorbent using diffuse reflectance spectroscopy as described in [31].

3.6. Analytical Performance. As mentioned above the complete desorption of $\mathrm{Co}$ (II) cannot be achieved with $1 \mathrm{M}$ $\mathrm{HNO}_{3}$ as effluent, so determination of $\mathrm{Cu}(\mathrm{II}), \mathrm{Fe}(\mathrm{III}), \mathrm{Ni}(\mathrm{II})$, $\mathrm{Al}(\mathrm{III}), \mathrm{Zn}(\mathrm{II})$, and $\mathrm{Pb}$ (II) was developed. The LODs values calculated using $3 s$ values for 10 blank measurements and preconcentration factors $(\mathrm{PF})$ and RSD are presented in Table 6.

The relative standard deviations (RSD) were calculated from the data obtained in five parallel adsorption-desorption experiments for each of the studied metal ions. The results showed that the RSD values of the method are lower than $2.5 \%$ and the method has good precision for the analysis of trace $\mathrm{Cu}(\mathrm{II}), \mathrm{Fe}(\mathrm{III}), \mathrm{Ni}(\mathrm{II}), \mathrm{Al}(\mathrm{III}), \mathrm{Zn}(\mathrm{II})$, and $\mathrm{Pb}$ (II) from solution samples.
The results of the comparison of the analytical performance of the developed method with other methods reported previously are shown in Table 7. As seen, LOD values obtained by this method are not inferior to those published earlier using different adsorbents. It should be noted that the LODs of elements decrease proportionally to the increase of the ratio of the sample volume to the volume of eluent used for desorption. In turn, the required sample volume depends on the concentration of elements to be determined, as well as on the adsorption capacity of the adsorbent used for preconcentration. Obviously, the larger sample volumes can be used for the adsorbents with higher adsorption capacity that also decreases LOD values.

It should be also noted that the mechanical strength of strong base anion-exchange polymer resins is not too high due to osmotic pressure observed for resin with quick changes in ionic strength and acid concentrations. Also, the preparation of polymer resin based adsorbents as well as nanocarbon containing adsorbents is significantly more expensive as compared to silica modified with organic 


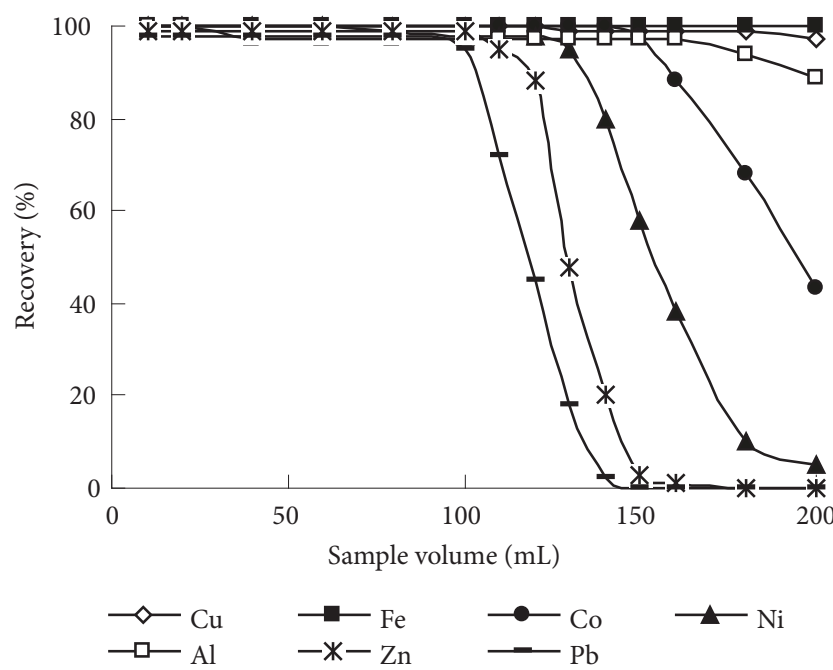

FIGURE 8: The effect of sample volume on metal recoveries for $\mathrm{SiO}_{2}$ PHMG-NRS. Mass of adsorbent in the column $0.1 \mathrm{~g}$, pH 6.5, and flow rate $1.5 \mathrm{~mL} \mathrm{~min}^{-1}$. Concentration of metals: $200 \mathrm{ng} \mathrm{mL}^{-1}$ of $\mathrm{Fe}(\mathrm{III}), 50 \mathrm{ng} \mathrm{mL} \mathrm{m}^{-1}$ of $\mathrm{Cu}(\mathrm{II}), \mathrm{Al}(\mathrm{III}), \mathrm{Zn}(\mathrm{II})$, and $20 \mathrm{ng} \mathrm{mL} \mathrm{m}^{-1}$ of $\mathrm{Co}(\mathrm{II}), \mathrm{Ni}(\mathrm{II}), \mathrm{Pb}(\mathrm{II})$.

reagents. Among silica based adsorbents included in Table 7 $\mathrm{SiO}_{2}$-PHMG-NNS demonstrated better selectivity towards many metal cations. Again, $\mathrm{SiO}_{2}$-PHMG-NNS was obtained by simple soaking (physical adsorption) of silica in aqueous solutions of PHMG and sulphonated nitrosonaphthols, and preparation of other silica based adsorbents required more complex treatment with functionalized silanes in organic solvents.

3.7. Effect of Sample Matrix. Normally natural waters contain substantial amounts of inorganic anions including chlorides, nitrates, sulphates, carbonates, and alkali and alkaline-earth metal cations, which can potentially influence adsorption of $\mathrm{Cu}(\mathrm{II}), \mathrm{Fe}(\mathrm{III}), \mathrm{Ni}(\mathrm{II}), \mathrm{Al}(\mathrm{III}), \mathrm{Zn}(\mathrm{II})$, and $\mathrm{Pb}(\mathrm{II})$ on studied adsorbents. A possible effect of excessive concentration of these ions on recovery of transition metals from solutions was studied. It was found that alkali $\left(\mathrm{Na}^{+}, \mathrm{K}^{+}\right)$and alkaline-earth $\left(\mathrm{Sr}^{2+}, \mathrm{Ca}^{2+}, \mathrm{Mg}^{2+}\right.$, and $\left.\mathrm{Ba}^{+}\right)$metal cations are not adsorbed by $\mathrm{SiO}_{2}$-PHMG-NRS or $\mathrm{SiO}_{2}$-PHMG-NNS from aqueous solutions with $\mathrm{pH} 6.5$. Also, the presence of up to $10 \mathrm{mg} \mathrm{L}^{-1}$ of $\mathrm{Cr}(\mathrm{III}), \mathrm{Cd}(\mathrm{II})$, and $\mathrm{Mn}(\mathrm{II})$ in the samples does not interfere with the recovery of $\mathrm{Cu}(\mathrm{II}), \mathrm{Fe}(\mathrm{III}), \mathrm{Ni}(\mathrm{II}), \mathrm{Al}(\mathrm{III}), \mathrm{Zn}(\mathrm{II})$, and $\mathrm{Pb}(\mathrm{II})$. These metals can be quantitatively extracted from the solutions (up to $5 \mathrm{~g} \mathrm{~L}^{-1}$ ) of $\mathrm{NaCl}, \mathrm{NaNO}_{3}, \mathrm{NaHCO}_{3}$, and $\mathrm{Na}_{2} \mathrm{SO}_{4}$, while a partial desorption of metals in a form of complexes with NRS and NNS was observed with further increase of salts concentrations to $10 \mathrm{~g} \mathrm{~L}^{-1}$ in the sample of $50 \mathrm{~mL}$ volume passed through the column.

3.8. Analysis of Natural Waters. The developed method was applied for ICP-OES determination of $\mathrm{Cu}(\mathrm{II}), \mathrm{Fe}(\mathrm{III}), \mathrm{Ni}(\mathrm{II})$, $\mathrm{Al}(\mathrm{III}), \mathrm{Zn}(\mathrm{II})$, and $\mathrm{Pb}(\mathrm{II})$ in natural waters. The samples included mineral waters Bay-Khaak (sample 1, Tuva Republic,
Russia) and Arzhaan-Suu (sample 2, Altai Republic, Russia) and river water (sample 3), collected in estuarine of US river (Krasnoyarsk region, Russia). Adsorbent $\mathrm{SiO}_{2}-\mathrm{PHMG}-$ NRS was used for analysis of samples 1 and 2, and adsorbent $\mathrm{SiO}_{2}$-PHMG-NNS was used for analysis of samples 2 and 3. The analytical results for each of the environmental water samples, including recoveries for spiked samples (standard addition calibration was used), are presented in Table 8. Data reported is the average of three separate analyses.

There is limited and controversial data in the literature regarding chemical composition of Arzhaan-Suu natural waters [43]. Arzhaan-Suu spring water is related to the groups of weakly alkaline $(\mathrm{pH}$ 8.6-9.0) hydrocarbonate magnesium-calcium containing mineral waters. The mineralisation degree of this water is $0.30-0.33 \mathrm{~g} \mathrm{~L}^{-1}$ and water hardness is moderate of $3.45-3.75 \mathrm{mg} \mathrm{L}^{-1}$ [40]. Additionally, average concentrations of $0.08-0.38 \mathrm{mg} \mathrm{L}^{-1}$ of fluorine, 3.0

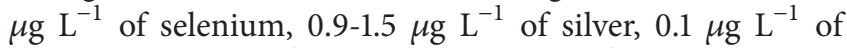
cadmium, $0.1 \mu \mathrm{g} \mathrm{L}^{-1}$ of mercury, $18 \mu \mathrm{g} \mathrm{L}^{-1}$ of lead, $2.4 \mathrm{mg}$ $\mathrm{L}^{-1}$ of silica, $90 \mu \mathrm{g} \mathrm{L}^{-1}$ of manganese, $70 \mu \mathrm{g} \mathrm{L}^{-1}$ of total iron, $8 \mu \mathrm{g} \mathrm{L}^{-1}$ of total chromium, $67 \mu \mathrm{g} \mathrm{L}^{-1}$ of calcium, and $28 \mu \mathrm{g} \mathrm{L}^{-1}$ of magnesium have been reported for this water. The results obtained in the present work (Table 8) are in good agreement with previously reported data. The added-found experiment is accomplished to validate the method.

\section{Conclusions}

A simple two-step method for the preparation of complexing adsorbents with nitrosonaphthol functional groups is developed. The first step included preparation of anion-exchanger by coating of silica surface with strongly adsorbed cationic polymer PHMG. Three different sulphonated nitrosonaphthols electrostatically retained by PHMG coated silica provided similar complexing properties for the selected transition metals. Interestingly, the adsorbents containing a weaker retained nitroso-N-salt exhibited the highest capacity for metal ions and the better preconcentration factors (up to 80). The adsorbents can be used for preconcentration of metals in analysis of natural waters with low concentrations of target metal ions. Fast adsorption kinetics of metals on $\mathrm{SiO}_{2}-\mathrm{PHMG}-\mathrm{NRS}$ and $\mathrm{SiO}_{2}-\mathrm{PHMG}-\mathrm{NNS}$ makes these adsorbents useful for possible applications as stationary phases in column liquid chromatography and flow injection analysis.

\section{Data Availability}

The data used to support the findings of this study are included within the article.

\section{Conflicts of Interest}

The authors declare that there are no conflicts of interest. 
TABLE 7: Comparison of analytical characteristics of the preconcentration methods for determination of elements in water samples.

\begin{tabular}{|c|c|c|c|c|c|}
\hline Adsorbent/chelating agent & Method & Element - LOD $\left(\mu \mathrm{g} \mathrm{L}^{-1}\right)$ & Eluent & PF & Ref. \\
\hline $\begin{array}{l}\text { Amberlite XAD-4/salicylaldehyde } \\
\text { benzoylhydrazone }\end{array}$ & FAAS & $\begin{array}{l}\mathrm{Cu}(\mathrm{II})-0.50, \mathrm{Ni}(\mathrm{II})-0.90 \\
\mathrm{Co}(\mathrm{II})-0.70, \mathrm{Fe}(\mathrm{III})-0.40\end{array}$ & $\begin{array}{c}10 \mathrm{~mL} 3 \mathrm{M} \mathrm{HNO}_{3} \text { in } \\
\text { acetone }\end{array}$ & 240 & {$[33]$} \\
\hline $\begin{array}{l}\text { Amberlite } \\
\text { XAD-16/p-aminobenzenesulfonic } \\
\text { acid }\end{array}$ & FAAS & $\begin{array}{c}\mathrm{Cu}(\mathrm{II})-0.72, \mathrm{Ni}(\mathrm{II})-0.89 \\
\mathrm{Zn}(\mathrm{II})-1.05, \mathrm{Co}(\mathrm{II})-0.98 \\
\mathrm{Cr}(\mathrm{III})-1.17, \mathrm{Fe}(\mathrm{III})-0.69 \\
\mathrm{~Pb}(\mathrm{II})-1.91\end{array}$ & 3-5 mL $2 \mathrm{M} \mathrm{HNO}_{3}$ & $60-100$ & {$[34]$} \\
\hline $\begin{array}{l}\text { Amberlite XAD-4/1-(2-pyridylazo)- } \\
\text { 2-naphthol }\end{array}$ & FAAS & $\begin{array}{c}\mathrm{Co}(\mathrm{II})-0.54, \mathrm{Ni}(\mathrm{II})-1.30 \\
\mathrm{Mn}(\mathrm{II})-0.20, \mathrm{Zn}(\mathrm{II})-0.28 \\
\mathrm{~Pb}(\mathrm{II})-1.10, \mathrm{Cu}(\mathrm{II})-0.42\end{array}$ & $\begin{array}{c}5 \mathrm{~mL} 2 \mathrm{M} \mathrm{HClO}_{4} \text { for } \\
\mathrm{Cu}(\mathrm{II}), \mathrm{Ni}(\mathrm{II}) ; 5 \mathrm{~mL} 2 \\
\mathrm{M} \mathrm{HNO}_{3} \text { for } \mathrm{Zn}(\mathrm{II}) \\
\mathrm{Co}(\mathrm{II}) ; 2.5 \mathrm{~mL} 0.5 \mathrm{M} \\
\mathrm{H}_{2} \mathrm{SO}_{4} \text { for } \mathrm{Cd}(\mathrm{II}) \\
\mathrm{Pb}(\mathrm{II}) \text { and } \mathrm{Mn}(\mathrm{II})\end{array}$ & $160-400 *$ & {$[35]$} \\
\hline $\begin{array}{l}\text { Chromosorb } \\
\text { 106-TAR/4-(2-thiazolylazo) } \\
\text { resorcinol }\end{array}$ & ICP-MS & $\begin{array}{c}\mathrm{Cu}(\mathrm{II})-0.012, \mathrm{Ni}(\mathrm{II})-0.0064 \\
\mathrm{~Pb}(\mathrm{II})-0.021, \mathrm{Zn}(\mathrm{II})-0.015\end{array}$ & $1 \mathrm{~mL}, 0.75 \mathrm{M} \mathrm{HNO}_{3}$ & 5 & {$[36]$} \\
\hline Silica/ $\mathrm{NH}_{2}$ & ICP-MS & $\begin{array}{c}\mathrm{Pb}(\mathrm{II})-0.699, \mathrm{Cd}(\mathrm{II})-0.123 \\
\mathrm{Zn}(\mathrm{II})-0.24\end{array}$ & $3 \mathrm{~mL}, 3 \mathrm{M} \mathrm{HNO}_{3}$ & 33.3 & {$[37]$} \\
\hline $\begin{array}{l}\text { Silica/N-(2-aminoethyl)-2,3- } \\
\text { dihydboxybenzaldimine }\end{array}$ & ICP-OES & $\begin{array}{c}\mathrm{Cd}(\mathrm{II})-0.012, \mathrm{Cu}(\mathrm{II})-0.098 \\
\mathrm{Ni}(\mathrm{II})-0.056, \mathrm{~Pb}(\mathrm{II})-0.14\end{array}$ & $5 \mathrm{~mL}, 0.5 \mathrm{M} \mathrm{HCl}$ & 100 & {$[38]$} \\
\hline $\begin{array}{l}\text { Silica/sodium } \\
\text { diethyldithiocarbamate }\end{array}$ & ICP-OES & $\mathrm{Co}(\mathrm{II})-0.198, \mathrm{Ni}(\mathrm{II})-0.201$ & $5 \mathrm{~m}, 2 \mathrm{MHNO}_{3}$ & 400 & {$[39]$} \\
\hline $\begin{array}{l}\text { GO Amberlite } \\
\text { XAD-16/picolylamine }\end{array}$ & ICP-OES & $\mathrm{Cu}(\mathrm{II})-0.048, \mathrm{~Pb}(\mathrm{II})-1.43$ & $5 \mathrm{~mL}, 2 \mathrm{MHCl}$ & 150 & {$[40]$} \\
\hline Multiwall carbon nanotubes / silica & ICP-OES & $\begin{array}{c}\mathrm{As}(\mathrm{V})-0.67, \mathrm{Cd}(\mathrm{II})-0.45 \\
\mathrm{Cu}(\mathrm{II})-0.11, \mathrm{Cr}(\mathrm{III})-0.91 \\
\mathrm{~V}(\mathrm{~V})-0.55, \mathrm{Zn}(\mathrm{II})-0.27\end{array}$ & $0.6 \mathrm{~mL}, 2 \mathrm{MHCl}$ & 10 & {$[41]$} \\
\hline $\mathrm{SiO}_{2}-\mathrm{PHMG}-\mathrm{NNS}$ & ICP-OES & $\begin{array}{l}\mathrm{Cu}(\mathrm{II})-0.75, \mathrm{Fe}(\mathrm{III})-0.82 \\
\mathrm{Al}(\mathrm{III})-1.35, \mathrm{Ni}(\mathrm{II})-0.96 \\
\mathrm{Zn}(\mathrm{II})-0.77, \mathrm{~Pb}(\mathrm{II})-0.88\end{array}$ & $5 \mathrm{~mL}, 1 \mathrm{MHNO}_{3}$ & $28-80$ & This work \\
\hline
\end{tabular}

* - for $0.5 \mathrm{mg}$ of sorbent

TABLE 8: The results of ICP-OES determination of metals in natural waters (sample volume $100 \mathrm{~mL}$ acidified with $5 \mathrm{~mL}$ of $1 \mathrm{M} \mathrm{HNO}_{3}$ ).

\begin{tabular}{|c|c|c|c|c|c|c|c|c|}
\hline \multirow{3}{*}{ Metal } & \multicolumn{4}{|c|}{$\mathrm{SiO}_{2}$-PHMG-NRS } & \multicolumn{4}{|c|}{$\mathrm{SiO}_{2}-\mathrm{PHMG}-\mathrm{NNS}$} \\
\hline & $\begin{array}{l}\text { Added, } \\
\text { ng mL } \mathrm{mL}^{-1}\end{array}$ & Found, ng mL $\mathrm{L}^{-1}$ & $\begin{array}{l}\text { Added, } \\
\text { ng mL }{ }^{-1}\end{array}$ & Found, $\mathrm{ng} \mathrm{mL}^{-1}$ & $\begin{array}{l}\text { Added, } \\
\text { ng mL } \mathrm{mL}^{-1}\end{array}$ & Found, $\mathrm{ng} \mathrm{mL}^{-1}$ & $\begin{array}{l}\text { Added, } \\
\text { ng mL }{ }^{-1}\end{array}$ & Found, $\mathrm{ng} \mathrm{mL}^{-1}$ \\
\hline & \multicolumn{2}{|c|}{ Sample 1} & \multicolumn{2}{|c|}{ Sample 2} & \multicolumn{2}{|c|}{ Sample 2} & \multicolumn{2}{|c|}{ Sample 3} \\
\hline \multirow{2}{*}{$\mathrm{Cu}(\mathrm{II})$} & - & $0.34 \pm 0.01$ & - & $2.32 \pm 0.04$ & - & $2.28 \pm 0.04$ & - & $0.97 \pm 0.01$ \\
\hline & 5.0 & $5.37 \pm 0.05^{a}$ & 5.0 & $7.33 \pm 0.07$ & 5.0 & $7.26 \pm 0.07$ & 5.0 & $5.99 \pm 0.06$ \\
\hline \multirow{2}{*}{$\mathrm{Fe}(\mathrm{III})$} & - & $0.72 \pm 0.01$ & - & $1.69 \pm 0.03$ & - & $1.71 \pm 0.03$ & - & $10.7 \pm 0.1$ \\
\hline & 5.0 & $5.72 \pm 0.05$ & 5.0 & $6.65 \pm 0.06$ & 5.0 & $6.69 \pm 0.06$ & 5.0 & $15.7 \pm 0.1$ \\
\hline \multirow{2}{*}{$\mathrm{Ni}(\mathrm{II})$} & - & $0.21 \pm 0.01$ & - & $0.60 \pm 0.02$ & - & $0.56 \pm 0.02$ & - & $2.85 \pm 0.04$ \\
\hline & 2.0 & $2.19 \pm 0.03$ & 2.0 & $2.58 \pm 0.03$ & 2.0 & $2.57 \pm 0.03$ & 2.0 & $4.82 \pm 0.04$ \\
\hline \multirow{2}{*}{$\mathrm{Al}(\mathrm{III})$} & - & $2.44 \pm 0.04$ & - & $4.02 \pm 0.04$ & - & $3.99 \pm 0.04$ & - & $7.33 \pm 0.08$ \\
\hline & 2.0 & $4.43 \pm 0.04$ & 2.0 & $6.01 \pm 0.06$ & 2.0 & $6.02 \pm 0.06$ & 2.0 & $9.40 \pm 0.10$ \\
\hline \multirow{2}{*}{$\mathrm{Zn}(\mathrm{II})$} & - & $1.62 \pm 0.03$ & - & $2.56 \pm 0.04$ & - & $2.49 \pm 0.04$ & - & $5.05 \pm 0.05$ \\
\hline & 2.0 & $3.60 \pm 0.04$ & 2.0 & $4.52 \pm 0.05$ & 2.0 & $4.52 \pm 0.05$ & 2.0 & $7.02 \pm 0.07$ \\
\hline \multirow{2}{*}{$\mathrm{Pb}(\mathrm{II})$} & - & $\mathrm{ND}^{b}$ & - & $0.20 \pm 0.02$ & - & $0.22 \pm 0.02$ & - & $0.48 \pm 0.03$ \\
\hline & 2.0 & $2.03 \pm 0.04$ & 2.0 & $2.23 \pm 0.04$ & 2.0 & $2.24 \pm 0.04$ & 2.0 & $2.50 \pm 0.04$ \\
\hline
\end{tabular}

$\bar{a} \bar{x} \pm s(n=5), \bar{x}$ - average for five determinations, $s$ - standard deviation, ${ }^{b} \mathrm{ND}$ - non-detected.

\section{Acknowledgments}

This study was supported by the Ministry of Education and Science of the Russian Federation (Project No. 4.6343.2017 for Siberian Federal University).

\section{References}

[1] A. T. Townsend, J. O'Sullivan, A. M. Featherstone, E. C. V. Butler, and D. J. Mackey, "The application of ICP-SMS, GF-AAS and HG-AFS to the analysis of water and sediment samples 
from a temperate stratified estuary," Journal of Environmental Monitoring, vol. 3, no. 1, pp. 113-120, 2001.

[2] Z. Wei, S. Sandron, A. T. Townsend, P. N. Nesterenko, and B. Paull, "Determination of trace labile copper in environmental waters by magnetic nanoparticle solid phase extraction and high-performance chelation ion chromatography," Talanta, vol. 135, pp. 155-162, 2015.

[3] N. Velitchkova, O. Veleva, S. Velichkov, and N. Daskalova, "Possibilities of high resolution inductively coupled plasma optical emission spectrometry in the determination of trace elements in environmental materials," Journal of Spectroscopy, vol. 2013, Article ID 505871, 12 pages, 2013.

[4] B. H. Fumes, M. R. Silva, F. N. Andrade, C. E. D. Nazario, and F. M. Lanças, "Recent advances and future trends in new materials for sample preparation," TrAC - Trends in Analytical Chemistry, vol. 71, pp. 9-25, 2015.

[5] W. A. Wan Ibrahim, L. I. Abd Ali, A. Sulaiman, M. M. Sanagi, and H. Y. Aboul-Enein, "Application of solid-phase extraction for trace elements in environmental and biological samples: a review," Critical Reviews in Analytical Chemistry, vol. 44, no. 3, pp. 233-254, 2014.

[6] A. Peristyy, B. Paull, and P. N. Nesterenko, "Ion-exchange properties of microdispersed sintered detonation nanodiamond," Adsorption, vol. 22, no. 3, pp. 371-383, 2016.

[7] M. He, L. Huang, B. Zhao, B. Chen, and B. Hu, "Advanced functional materials in solid phase extraction for ICP-MS determination of trace elements and their species - A review," Analytica Chimica Acta, vol. 973, pp. 1-24, 2017.

[8] G. Alberti, V. Amendola, M. Pesavento, and R. Biesuz, "Beyond the synthesis of novel solid phases: review on modelling of sorption phenomena," Coordination Chemistry Reviews, vol. 256, no. 1-2, pp. 28-45, 2012.

[9] D. Caldarola, D. P. Mitev, L. Marlin et al., "Functionalisation of mesoporous silica gel with 2-[(phosphonomethyl)-amino] acetic acid functional groups. Characterisation and application," Applied Surface Science, vol. 288, pp. 373-380, 2014.

[10] G. Z. H. Amirova, T. A. Bolshova, and P. N. Nesterenko, "Use of 3-hydroxo-4-nitrosonaphtalene -2,7-disulfonic acid as a component of mobile phase in high-performance liquidchromatography," Vestnik Moskovskogo Universiteta. Seria 2. Khimia, vol. 33, pp. 68-71, 1992 (Russian).

[11] I. I. Seifullina and L. S. Skorokhod, "Naphthalenesulfonic acids as ligands of coordination-compounds of 3D-metals," Zhurnal Neorganicheskoi Khimii, vol. 38, pp. 1191-1201, 1993 (Russian).

[12] H. Sirén and M.-L. Riekkola, "Separation and determination of metals as complexes of 1-nitroso-2-naphthol-6-suiphonic and 2-nitroso-1-naphthol-6-sulphonic acids. II. Liquid chromatography on c18 bonded and copolymer stationary phases," Microchimica Acta, vol. 98, no. 1-3, pp. 77-90, 1989.

[13] J. P. Ghosh and H. R. Das, "Preparation and properties of a new chelating resin containing 1-nitroso-2-naphthol as the functional group," Talanta, vol. 28, no. 4, pp. 274-276, 1981.

[14] J. P. Ghosh, J. Pramanick, and H. R. Das, "Preparation and properties of a new chelating resin containing 2-nitroso-1naphthol," Talanta, vol. 28, no. 12, pp. 957-959, 1981.

[15] M. C. Gennaro, E. Mentasti, and C. Sarzanini, "Immobilized ligands on silica: uptake of cobalt and other metals by 1-nitroso2-naphthol," Polyhedron, vol. 5, no. 4, pp. 1013-1015, 1986.

[16] M. Kubo, T. Yano, H. Kobayashi, and K. Ueno, "Analytical application of organic reagents in hydrophobic gel mediaIV Selective preconcentration of Cobalt(II) with 1-nitroso-2naphthol gel," Talanta, vol. 24, no. 8, pp. 519-521, 1977.
[17] F. A. Aydin and M. Soylak, "Separation, preconcentration and inductively coupled plasma-mass spectrometric (ICP-MS) determination of thorium(IV), titanium(IV), iron(III), lead(II) and chromium(III) on 2-nitroso-1-naphthol impregnated MCI GEL CHP20P resin," Journal of Hazardous Materials, vol. 173, no. 1-3, pp. 669-674, 2010.

[18] K. Terada and K. Nakamura, "Preconcentration of cobalt(II) in natural waters with 1-nitroso-2-naphthol supported on silica gel," Talanta, vol. 28, no. 2, pp. 123-125, 1981.

[19] D. Bilba, C. Paduraru, and L. Tofan, "Determination of trace amounts of palladium(II) by solid-phase spectrophotometry," Microchimica Acta, vol. 144, no. 1-3, pp. 97-101, 2004.

[20] R. Stella, M. T. G. Valentini, and L. Maggi, "Cobalt preconcentration on a nitroso-R salt functional resin and elution with titanium(III)," Analytical Chemistry, vol. 57, no. 9, pp. 1941-1943, 1985.

[21] Z. Moldovan, L. Vlǎdescu, and E. Neagu, "Retention of Nitroso R-Salt on anionic resins: application to the preconcentration and separation of metal ions," Revue Roumaine de Chimie, vol. 43, no. 3, pp. 193-196, 1993.

[22] L. Tofan, "Solid-phase spectrophotometry use for the determination of trace amounts of Rh(III)," Reviews in Analytical Chemistry, vol. 30, no. 3-4, pp. 171-175, 2011.

[23] M. Wawrzkiewicz and Z. Hubicki, "Application of nitroso-R-salt in modification of strongly basic anion-exchangers Amberlite IRA-402 and Amberlite IRA-958," Desalination, vol. 249, no. 3, pp. 1228-1232, 2009.

[24] R. Kocjan, "Silica gel modified with some sulfonated chelating reagents as a sorbent for the preconcentration, isolation and separation of metal ions," Chemia Analityczna, vol. 41, no. 4, pp. 501-519, 1996.

[25] R. Kocjan and R. Świeboda, "Analytical application of silica gel modified with 2-nitroso-1-naphthol-4-sulfonic acid," Chemia Analityczna, vol. 43, no. 4, pp. 657-667, 1998.

[26] S. L. Didukh, N. V. Maznyak, and V. N. Losev, "Sorptionphotometric and test-determination of palladium using silica modified with polyhexamethylene guanidine and nitroso-Rsalt," Industrial Laboratory.Diagnostics of Materials, vol. 82, pp. 22-25, 2016 (Russian).

[27] V. N. Losev, S. L. Didukh, A. N. Mukhina, and A. K. Trofimchuk, "Using silica modified by poly(hexamethylene guanidine) and nitroso-R-salt for the preconcentration and determination of cobalt," Journal of Analytical Chemistry, vol. 70, no. 6, pp. 677684, 2015.

[28] V. N. Losev, S. L. Didukh, A. K. Trofimchuk, and V. N. Leshchenko, "Palladium(II) and cobalt(II) sorption by silica gel sequentially modified by polyhexamethylene guanidine and a nitroso-R salt," Mendeleev Communications, vol. 19, no. 3, pp. 167-169, 2009.

[29] S. Didukh, V. Losev, A. Mukhina, A. Trofimchuk, and P. Nestrenko, "Determination of cobalt in soils and natural waters using silica gel modifiedwith polyhexamethylene guanidine and nitroso-N-salt," Journal of Chemistry: Education Research and Practice, vol. 2, no. 1, pp. 1-10, 2018.

[30] P. N. Nesterenko and P. Jones, "Recent developments in the high-performance chelation ion chromatography of trace metals," Journal of Separation Science, vol. 30, pp. 1773-1793, 2007.

[31] A. D. Dadashev, V. A. Tertykh, E. S. Yanovskaya, E. V. Ryabchenko, K. V. Yanova, and V. S. Kutyanina, "Complexing properties of polyhexamethyleneguanidine chemically grafted to a silica surface," Russian Journal of Inorganic Chemistry, vol. 57, no. 4, pp. 485-491, 2012. 
[32] L. G. Sillen, A. E. Martell, and J. Bjerrum, Stability Constants of Metalion Complexes, Special Publication N 17, Chemical Society, London, UK, 2nd edition, 1964.

[33] G. Alpdoğan, "Solid phase extraction of $\mathrm{Cu}$ (II), Ni (II), Co (II), and Fe (III) ions in water samples using salicylaldehyde benzoylhydrazone on Amberlite XAD-4 and their determinations by flame atomic absorption spectrometry," Toxicological \& Environmental Chemistry, vol. 98, no. 2, pp. 179-188, 2015.

[34] A. Islam, A. Ahmad, and M. A. Laskar, "Flame atomic absorption spectrometric determination of trace metal ions in environmental and biological samples after preconcentration on a newly developed Amberlite XAD-16 chelating resin containing p-aminobenzene sulfonic acid," Journal of AOAC International, vol. 98, no. 1, pp. 165-175, 2015.

[35] A. Islam, M. A. Laskar, and A. Ahmad, "The efficiency of Amberlite XAD-4 resin loaded with 1-(2-pyridylazo)-2- naphthol in preconcentration and separation of some toxic metal ions by flame atomic absorption spectrometry," Environmental Modeling \& Assessment, vol. 175, no. 1-4, pp. 201-212, 2011.

[36] F. Zereen, V. Yilmaz, and Z. Arslan, "Multielement solid phase preconcentration using a chelating resin of styrene divinylbenzene copolymer and application for the analysis of seawater and fish otoliths by inductively coupled plasma mass spectrometry (ICP-MS)," Analytical Letters, vol. 47, no. 1, pp. 58-76, 2014.

[37] M. A. Habila, Z. A. ALOthman, A. M. El-Toni, and M. Soylak, "Combination of syringe-solid phase extraction with inductively coupled plasma mass spectrometry for efficient heavy metals detection," Clean - Soil, Air, Water, vol. 44, no. 6, pp. 720-727, 2016.

[38] E. Durduran, H. Altundag, M. Imamoglu, S. Z. Yildiz, and M. Tuzen, "Simultaneous ICP-OES determination of trace metals in water and food samples after their preconcentration on silica gel functionalized with $\mathrm{N}$-(2-aminoethyl)-2,3dihydroxybenzaldimine," Journal of Industrial and Engineering Chemistry, vol. 27, pp. 245-250, 2015.

[39] M. Sadia, M. R. Jan, J. Shah, and G. M. Greenway, "Simultaneous preconcentration and determination of nickel and cobalt using functionalised mesoporous silica spheres by ICP-OES," International Journal of Environmental Analytical Chemistry, vol. 93, no. 14, pp. 1537-1556, 2013.

[40] H. Javed, A. Islam, A. Chauhan, S. Kumar, and S. Kumar, "Efficacy of engineered GO Amberlite XAD-16 picolylamine sorbent for the trace determination of $\mathrm{Pb}$ (II) and $\mathrm{Cu}$ (II) in fishes by solid phase extraction column coupled with inductively coupled plasma optical emission spectrometry," Scientific Reports, vol. 8, no. 1, Article ID 17560, 2018.

[41] H. Peng, N. Zhang, M. He, B. Chen, and B. Hu, "Multi-wall carbon nanotubes chemically modified silica microcolumn preconcentration/separation combined with inductively coupled plasma optical emission spectrometry for the determination of trace elements in environmental waters," International Journal of Environmental Analytical Chemistry, vol. 96, no. 3, pp. 212224, 2016.

[42] P. Nesterenko, "Ion exchange .Overview," in Encyclopedia of Analytical Science, P. Worsfold, A. Townshend, C. Poole, and M. Miró, Eds., vol. 5, pp. 204-2010, Elsevier, 3rd edition, 2019.

[43] Red book of Altai Republic, Specially Protected Territories and Objects, Gorno-Altaisk, 2002. 

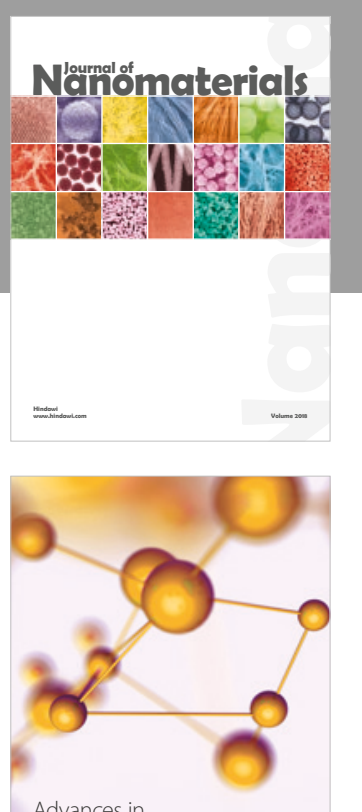

Physical Chemistry
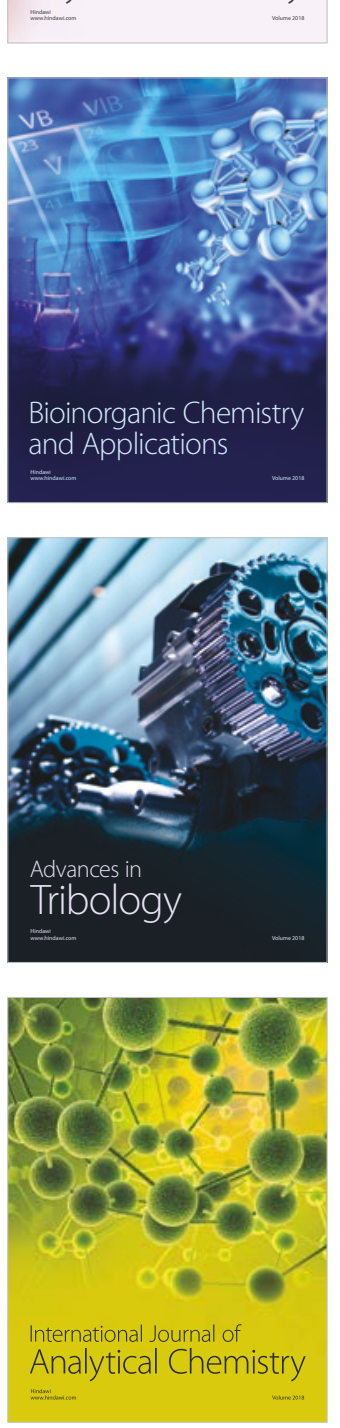

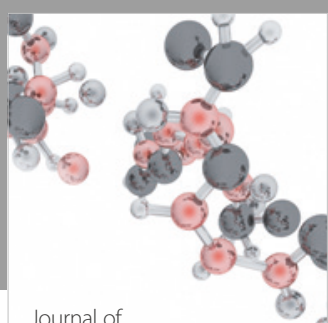

Analytical Methods in Chemistry

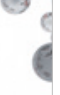

\section{The Scientific World Journal}
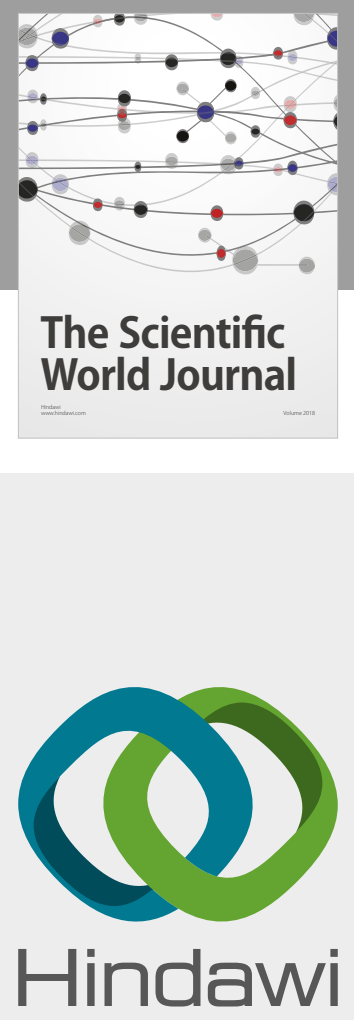

Submit your manuscripts at

www.hindawi.com
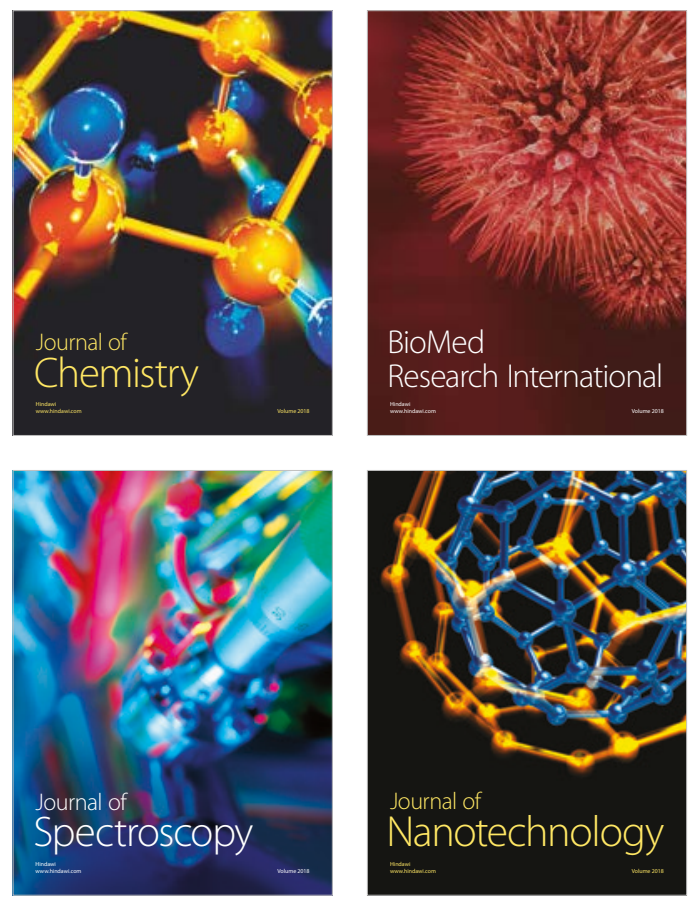

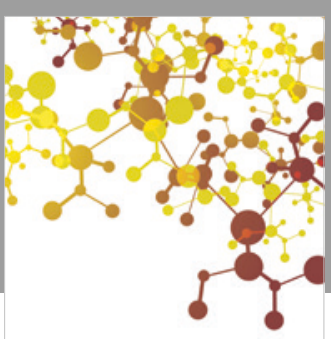

Apurnal of
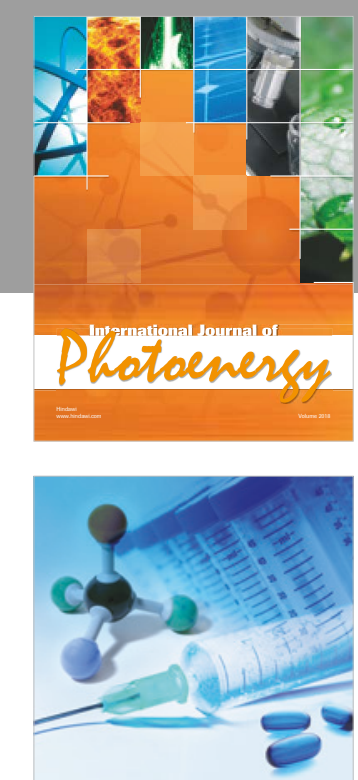

International Journal of Medicinal Chemistry
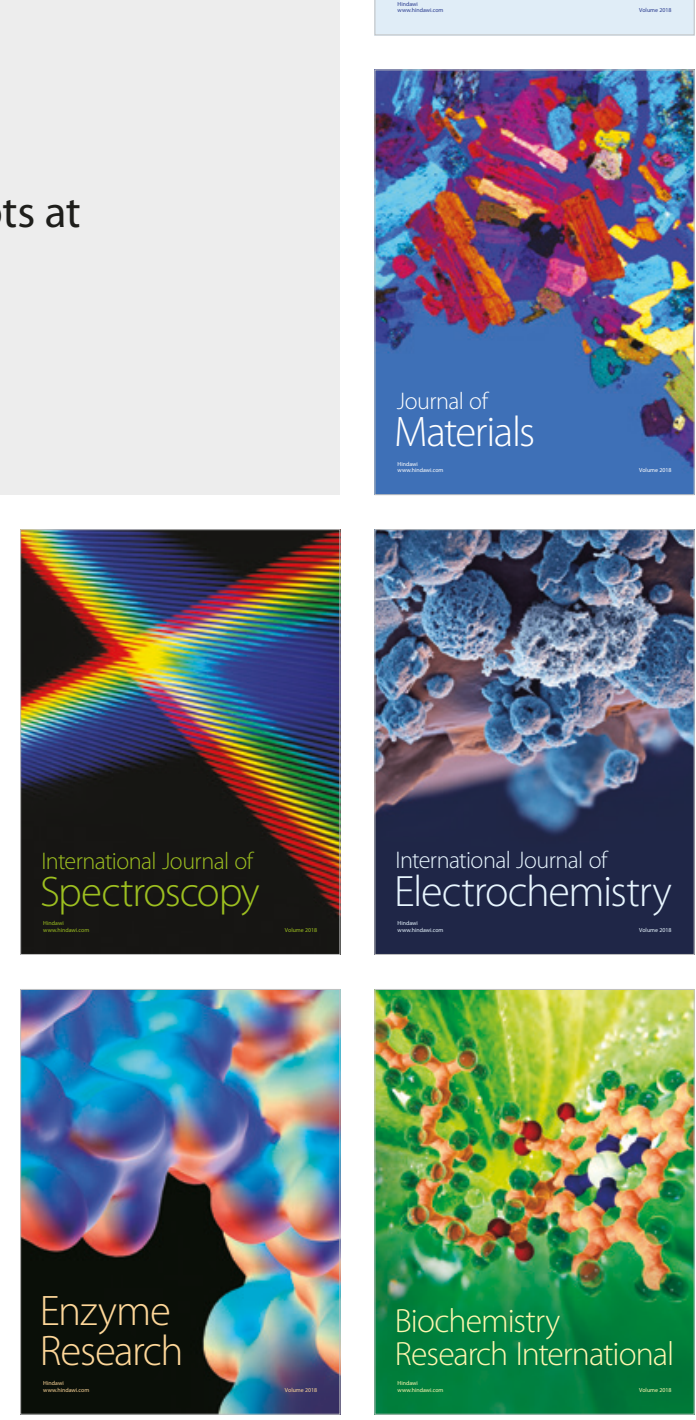
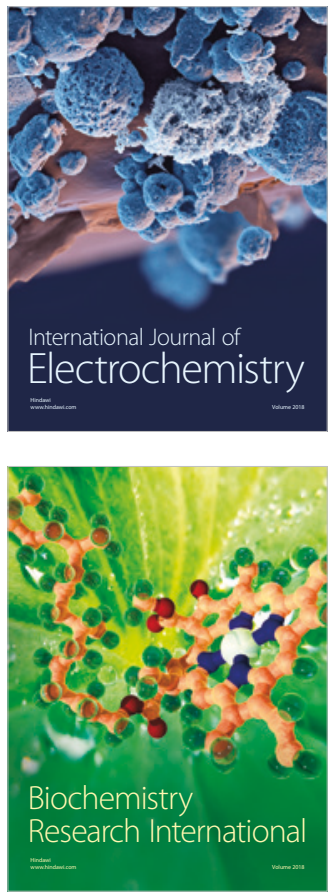